\title{
Innovative Development on Agglomeration of Iron Ore Fines and Iron Oxide Wastes
}

\section{Jagannath Pal}

To cite this article: Jagannath Pal (2019) Innovative Development on Agglomeration of Iron Ore Fines and Iron Oxide Wastes, Mineral Processing and Extractive Metallurgy Review, 40:4, 248-264, DOI: $10.1080 / 08827508.2018 .1518222$

To link to this article: https://doi.org/10.1080/08827508.2018.1518222

Published online: 08 Oct 2018.

Submit your article to this journal $\sqsubset$

山 Article views: 170

Q View related articles ๔

View Crossmark data $\nearrow$ 


\title{
Innovative Development on Agglomeration of Iron Ore Fines and Iron Oxide Wastes
}

\author{
Jagannath Pal \\ Metal Extraction and Recycling Division, CSIR-National Metallurgical Laboratory, Jamshedpur, India
}

\begin{abstract}
In steel industry and in mines, a significant amount of ultra-fines waste iron oxides and iron ore fines is generated. Utilizations of these fines are required to reduce the environmental hazards and conserve the natural resources. Some of these fines are normally used in sintering practice. However, sintering has a limitation of accepting ultra-fines materials. Pelletizing can use ultra-fine iron oxides. However, suitable technology is required for preparation of good quality pellets. Some of the fines, viz. blast furnace (BF) flue dust, Linz Donawitz (LD) converter sludge etc., are not suitable due to their high alkali and $\mathrm{Zn}$ content. Some other material like slime is not considered to be suitable in normal pelletizing practice, because of its high alumina and silica content and excessively fine size. On the other hand mill scale and blue dust have poor green bonding property. Therefore, suitable technologies are required to be developed for their utilization/recycling. This paper discusses the various technologies developed such as (i) developing flux for basic oxygen steelmaking process, (ii) improved pelletizing practice for better reducibility, lower reduction degradation and replacing bentonite binder, and (iii) special quality sinters for improving micro-fines utilization. These technologies may have very good application potential.
\end{abstract}

\section{KEYWORDS}

Ultra-fines; waste iron oxide; pelletizing; sintering; flux for steel making; micro pelletizing; replacement of bentonite; pellet-sinter composite agglomerate

\section{Introduction}

Iron ore is available in nature in form of hematite, magnetite, goethite, limonite etc. Out of which hematite and magnetite are the major source. Hematite can be used directly in iron making furnaces in lump form. Magnetite is generally used after pre processing. In India, the graded hematite lump is widely used in the blast furnaces and in rotary kiln. However, during the lump ore preparation $(10-30 \mathrm{~mm}$ size) lots of mineral dressing (crushing, grinding, screening etc.) are required wherein a significant amount of fines $(\sim 60 \%)$ are generated. These fines cannot be used directly in any furnaces. For utilization of these fines, agglomeration techniques, such as sintering, pelletizing, or briquetting, are required. Sintering is the oldest, easiest, and energy-efficient process to use these fines. Therefore, in most of the steel plant sintering routes are followed for using these undersize iron ore. However, sintering has a size limitation. Excessive fineness $(<0.5 \mathrm{~mm})$ loses its bed permeability. However, a huge quantity of ultra-fines iron oxides is generated both in the mines area and in the steel plant itself.

Main source of generation of ultra-fines in mines area is the ore washing plant. During water washing of iron ore lump, the ultra-fines (majority is below $30 \mu \mathrm{m}$ ) are separated in form of slurry. This is very rich in alumina (3-15\%) and silica $(3-15 \%)$. This slurry is termed as slime. Due to the high gangue content and excessive fineness, the entire slime is still unused.

Due to the weathering of iron ore hills for several thousand years in rainwater, erupted iron ore particles are deposited at the several cavities of hills. They are very clean and rich in iron, because of washing by the rain water. As there is very little gangue, they have hardly any bonding property and they are available in form of fines or dust in blue colors. Therefore, they are termed as 'blue dust'. They are used in pelletizing mix with hematite ore in a low percentage because of their poor green bonding property (Pal et al. 2017a). As they have very low gangue content, the pellets gangue content is proportionally reduced, which may improve the pellet property and increase the performance of the downstream process by reducing slag volume. However, $100 \%$ blue dust use is essential to conserve the natural resources.

Apart from these, there are lean grade ores which are not used directly in the blast furnace or DRI making. These ores are generally crushed and ground to powdery size and are upgraded through several beneficiation processes. The beneficiated products are available in form of fines which require agglomeration before using in iron making furnaces.

Magnetite ore is also a good source of iron. Out of 170 billion tonnes (Indian mineral year Book 2012) iron ore deposit worldwide, around $40 \%$ is magnetite. Magnetite lump ore has very poor reducibility. It is much denser than hematite and has lower porosity. Furthermore, when hematite ore is reduced to magnetite its structure changes from hexagonal close-packed (HCP) to cubic which causes volume expansion by $23 \%$. Due to this volume expansion, several cracks are generated in the lumps. Therefore, reducing gas can pass easily which enhances the reduction of ore. However, in magnetite ore, this phenomenon does not occur. Therefore, the magnetite ore is generally crushed and ground to fines and after pelletizing and heat hardening these are used in iron 
making furnaces. These pellets show much better reducibility due to the presence of pores which allow gas to pass through.

Undersized iron ore fines generated in raw materials handling section are used in sinter plant in regular basis. The micro fines like blue dust and concentrates available from the lean grade ore are used in pelletizing plant. Therefore, in present scenario these undersized fines are not a problem in steel plant. However, a considerable part of other fines generated in deferent sections of plants such as blast furnace flue dust (BFD), LD sludge (LDS), mills scale etc. still remain unused. A brief account of it is given below.

Different types of wastes generated in a typical steel plant with their major constituents, harmful, or beneficial, are listed in Table 1 (Yadav et al. 2002). These oxide wastes are in general recycled as a part of the charge mix during sintering of iron ore fines. It has been reported that several sinter plants in the world recycle (Basu et al. 1997, 2002) up to $180-200 \mathrm{~kg}$ of waste oxides per ton of sinter, whereas in India this rate is slightly lower, at $100-170 \mathrm{~kg}$ per ton of sinter (Basu et al. 2002). Some iron oxide wastes, like LD and BF sludge, contain zinc and alkalis for which they are not favorable for direct recycling. In India, fortunately, the zinc content of LD sludge is not adverse (Basu et al. 2002). However, these waste materials except slag have excessive fineness below $100 \mu \mathrm{m}$ size which cannot be used fully in the iron ore sintering due to the permeability problem. These unused iron oxide fines are termed as 'Waste Iron Oxides' (WIO). The typical analysis and generation rate of some of the important WIO are shown in Table 2.

Uses of these waste oxides are imperative to reduce the environmental hazards and conservation of natural resources. It has been mentioned above that undersize iron ore fines available from raw materials handling sections are used in the conventional sintering practice. On the other hand, the microfines of iron oxides (concentrates) available from beneficiation plant are used in pelletizing practice. However, these conventional practices are not sufficient to use all iron oxide microfines generated in steel plant as well as in the mines area. Therefore, a considerable improvement in present technology is required. Some innovative developments, carried out on their utilization are presented in brief in the proceeding sections of this paper.

\section{Some important development on micro-fines utilization}

In order to utilize micro-fines, pelletizing is the conventional practice since several decades. However, innovative approaches are required to improve the use of micro-fines in sintering. In some of the micro-fines, there are limitations related to their chemistry like alkali and high gangue problems for using in BF. However, these can be used in either steel making as coolant or in alternative processes. Our approaches for the development on utilization of micro-fines are described as follows.

\subsection{Utilization of steel plant waste and iron ore fines}

With the advent of continuous casting, which reduces the supply of home scrap, steelmakers are facing a daunting task of process adjustment to accommodate scrap from open market with widely varying chemical composition. Fluctuations in availability and chemistry of market scrap are also problems of using scrap.

Iron ore lump is usually charged into the basic oxygen furnace (BOF) as a coolant (as well as a stirring agent); also, it is often used as a scrap substitute. These contain lower amount of residual elements such as copper, zinc, nickel, and molybdenum. In recent times, methods have been developed to use waste oxides as well as sponge iron in the BOF in place of ore.

In the basic oxygen steelmaking, burnt lime consumption is in the range of $18-45 \mathrm{~kg}$ per ton of steel produced. Use of lump lime of specific sizes causes rejection of all undersized lime, adding to the cost of production. Moreover, lime, being a lighter material, does not quickly go into the solution during the bath turbulence caused by the oxygen blowing and, being a refractory oxide, increases the blow time of refining. A

Table 1. Different waste materials in steel plants.

\begin{tabular}{|c|c|c|c|c|}
\hline Wastes & Sources & Desirable constituents & Undesirable constituents & Harmful constituents \\
\hline $\begin{array}{l}\text { BF slag } \\
\text { BF dust } \\
\text { BF sludge } \\
\text { External Desulphurization slag } \\
\text { LD slag } \\
\text { LD sludge } \\
\text { Secondary steel making slag } \\
\text { Mill scale } \\
\text { Semi-calcined lime }\end{array}$ & $\begin{array}{l}\text { Blast furnace } \\
\text { Dust catcher of blast furnace } \\
\text { Gas cleaning plant of blast furnace } \\
\text { LD converter } \\
\text { Gas cleaning plant of LD converter } \\
\text { Secondary steel making } \\
\text { Rolling mills } \\
\text { Lime plant }\end{array}$ & $\begin{array}{l}\mathrm{CaO} \\
\text { Fe oxides, } \mathrm{C} \\
\text { Fe oxides, C } \\
\mathrm{CaO} \\
\mathrm{CaO}, \mathrm{FeO} \\
\mathrm{CaO}, \mathrm{FeO} \\
\mathrm{CaO} \\
\mathrm{Fe} \text { Oxides } \\
\mathrm{CaO}\end{array}$ & $\begin{array}{l}\mathrm{Al}_{2} \mathrm{O}_{3}, \mathrm{SiO}_{2} \\
\mathrm{Al}_{2} \mathrm{O}_{3}, \mathrm{SiO}_{2} \\
\mathrm{SiO}_{2} \\
\mathrm{~S}_{1} \mathrm{SiO}_{2} \\
\mathrm{Al}_{2} \mathrm{O}_{3}, \mathrm{SiO}_{2} \\
- \\
\mathrm{Al}_{2} \mathrm{O}_{3} \\
- \\
\text { Loss on ignition }\end{array}$ & $\begin{array}{l}\mathrm{S}, \mathrm{Na}_{2} \mathrm{O}, \mathrm{K}_{2} \mathrm{O} \text { (for iron making) } \\
\mathrm{Na}_{2} \mathrm{O}, \mathrm{K}_{2} \mathrm{O} \text { (for iron making) } \\
\mathrm{S}, \mathrm{Na}_{2} \mathrm{O}, \mathrm{K}_{2} \mathrm{O} \text { (for iron making) } \\
\mathrm{S}, \mathrm{Na}_{2} \mathrm{O}, \mathrm{K}_{2} \mathrm{O} \text { (for iron making) } \\
\mathrm{P} \text { (for steel making) } \\
\mathrm{Zn} \\
\mathrm{Al}_{2} \mathrm{O}_{3}, \mathrm{SiO}_{2} \text { (for iron making) } \\
\text { Oil (for sintering) }\end{array}$ \\
\hline
\end{tabular}

Table 2. Typical composition of waste iron oxides (Ambesh 2007; Yadav et al. 2002; Basu et al. 2002).

\begin{tabular}{|c|c|c|c|c|c|c|c|c|c|c|c|}
\hline \multirow[b]{2}{*}{ Wastes } & \multirow[b]{2}{*}{ Generation rate } & \multicolumn{10}{|c|}{ Chemical analysis, wt $\%$} \\
\hline & & $\mathrm{Fe}_{\mathrm{t}}$ & $\mathrm{CaO}$ & $\mathrm{SiO}_{2}$ & $\mathrm{MgO}$ & $\mathrm{Al}_{2} \mathrm{O}_{3}$ & $\mathrm{P}$ & $S$ & C & $\mathrm{K}_{2} \mathrm{O}$ & $\mathrm{Na}_{2} \mathrm{O}$ \\
\hline Iron ore fines & $60 \%$ of total iron ore production & $55-65$ & - & $1-4$ & - & $1-3.5$ & $0.01-0.05$ & $0.01-0.05$ & - & & \\
\hline Blue dust & - & $60-67$ & - & $1-3$ & - & $1-3$ & $0.02-0.05$ & $0.02-0.05$ & - & & \\
\hline BF sludge & $1 \mathrm{~kg} / \mathrm{tcs}$ & 33.6 & 3.45 & 6.40 & 1.40 & 3.64 & 0.31 & 0.23 & 21 & 0.40 & 0.20 \\
\hline Mill scale & $10-20 \mathrm{~kg} / \mathrm{tcs}$ & 70.2 & 0.31 & 0.55 & 0.16 & 0.27 & 0.03 & - & - & - & - \\
\hline Flue dust & $1-2 \mathrm{~kg} / \mathrm{tcs}$ & 39.5 & 3.66 & 7.9 & 1.34 & 3.0 & 0.17 & 0.32 & 25.2 & 0.34 & 0.15 \\
\hline
\end{tabular}


certain percentage of lime usually gets carried by the exit gas from the converter, increasing the load in the dust catching system.

The aforesaid problems associated with the use of scrap and lime necessitate identifying a suitable alternative feed material which will be free from such limitations. Lime iron oxide combination can yield a $\mathrm{CaO}-\mathrm{Fe}_{\mathrm{x}} \mathrm{O}$ eutectic slag, which has melting point to be around $1230^{\circ} \mathrm{C}$ as shown in Figure 1 (Verein Deutscher Eisenhulttenleute 1981). Fluxing iron ore fines with lime powders and agglomerating it into a suitable agglomerate and using this agglomerate as flux may be one solution to get a low melting basic and oxidizing slag. Several investigators have agglomerated iron oxide fines in form of briquettes (Balajee et al. 1995; Dukelow et al. 1995; Lherbier and Green 1995; Landow et al. 1998; Catherine and Freuhan 2000), sinters (Irmler et al. 2003), or pellets (Imazumi 1991; Choi and Kim 2002) and used in BOF. But, there are certain difficulties about preparations of sinters and briquettes. For example, in sintering, the restriction of very fine materials and a high temperature requirement limit the scope of utilization of ultra fine iron ore. Similarly, in briquetting, organic binders are very costly and inorganic binders contain very high silica and alumina which increases slag volume in the downstream process. Therefore, a low-cost feed material in the form of fluxed iron oxide pellets or super fluxed sinter from waste iron oxides has been produced in our study. Such agglomerates in contact with the liquid iron bath may impart the following two benefits: (i) early formation of primary slag, facilitating the onset of refining reaction and hence a reduction in tap-to-tap time and (ii) better utilization of raw materials/wastes.

\subsubsection{Binderless cold bonded super fluxed pellet}

In order to produce the low melting oxidizing flux, the waste oxides of steel plant and iron ore fines have been agglomerated in presence of high percentage of burnt or hydrated lime. Pelletizing route has been followed. Since, the pellet needs to be charged in to BOF its minimum handling strength is required. Induration at high temperature can increase the pellet strength, however, it is a very cost intensive process. In this purpose many investigators have used costly binders. But, binders contain high alumina and silica which may increase the slag volume in the downstream process. Therefore, a new technique has been developed to bind the fluxed pellet by treating it with industrial waste gas, which contains a significant amount of carbon dioxide [16]. This process neither requires any high temperature curing nor any binder. Pellet thus prepared is termed as 'Fluxed Lime Iron oxide Pellet' (FLIP)

Initially, during pellet making calcined or slacked lime in presence of sufficient moisture provides green bonding. After drying also a poor bonding is observed in pellet. Further, upon treatment with industrial waste gas $/ \mathrm{CO}_{2}$ at room temperature the hydrated lime reacted with $\mathrm{CO}_{2}$ gas to impart the cold strength. The mechanism for this room temperature strengthening is as follows ( $\mathrm{Pal}$ et al. 2009a, 2009b)

When the lime $(\mathrm{CaO})$, present in the base mixture, comes in contact with added water before pelletizing, it reacts to form calcium hydroxide:

$$
\mathrm{CaO}(\mathrm{s})+\mathrm{H}_{2} \mathrm{O}(\mathrm{l})=\mathrm{Ca}(\mathrm{OH})_{2}(\mathrm{~s}) ; \Delta \mathrm{H}=-65.3 \mathrm{~kJ}
$$

On pelletizing, this calcium hydroxide provides primary bonding amongst the particles and imparts strength to the green pellets. During subsequent treatment of the partially air-dried green pellets by a stream of $\mathrm{CO}_{2}$, the $\mathrm{Ca}(\mathrm{OH})_{2}$ transforms to $\mathrm{CaCO}_{3}$ according to the following reaction:

$$
\mathrm{Ca}(\mathrm{OH})_{2}(\mathrm{~s})+\mathrm{CO}_{2}(\mathrm{~g})=\mathrm{CaCO}_{3}(\mathrm{~s})+\mathrm{H}_{2} \mathrm{O}(\mathrm{g}) ; \Delta \mathrm{H}=-69.41 \mathrm{~kJ}
$$

$\mathrm{CO}_{2}$ enters through the pores of the partially dry pellets and forms carbonate. The XRD pattern of lime fluxed pellet before and after $\mathrm{CO}_{2}$ treatment is shown in Figure 2 (Pal et al. 2009a). After $\mathrm{CO}_{2}$ treatment, the figure mainly shows $\mathrm{CaCO}_{3}$ peaks

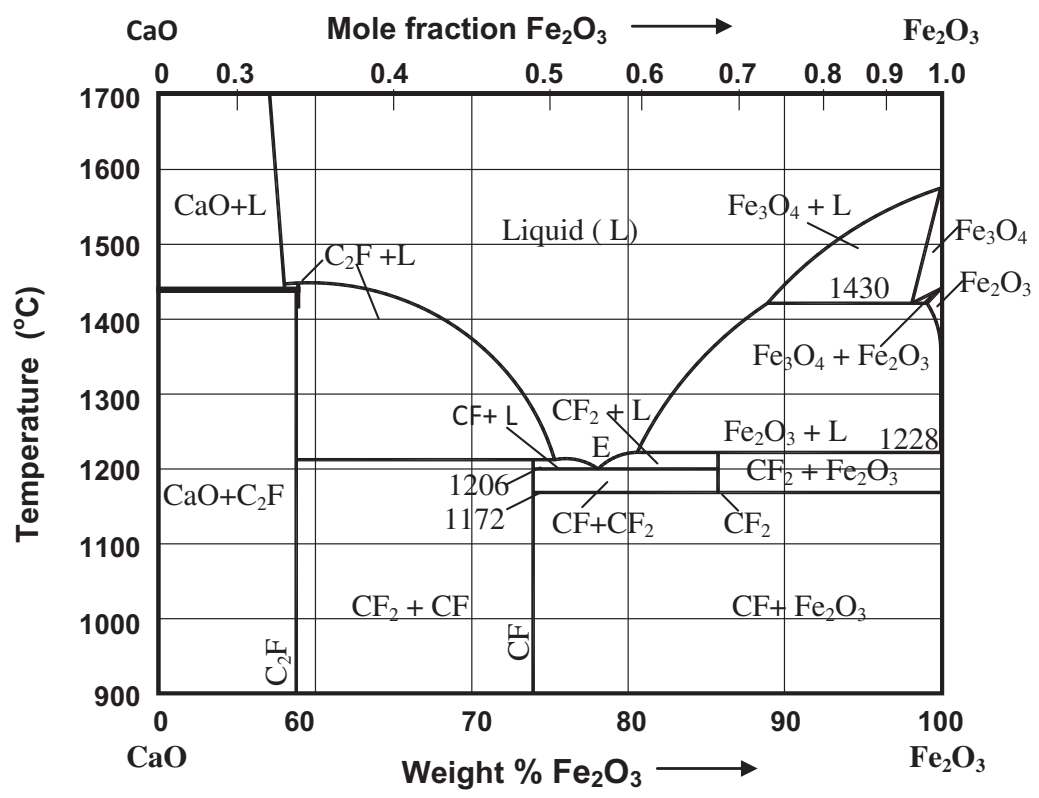

Figure 1. Binary Phase diagram of $\mathrm{Fe}_{2} \mathrm{O}_{3}-\mathrm{CaO}$. 


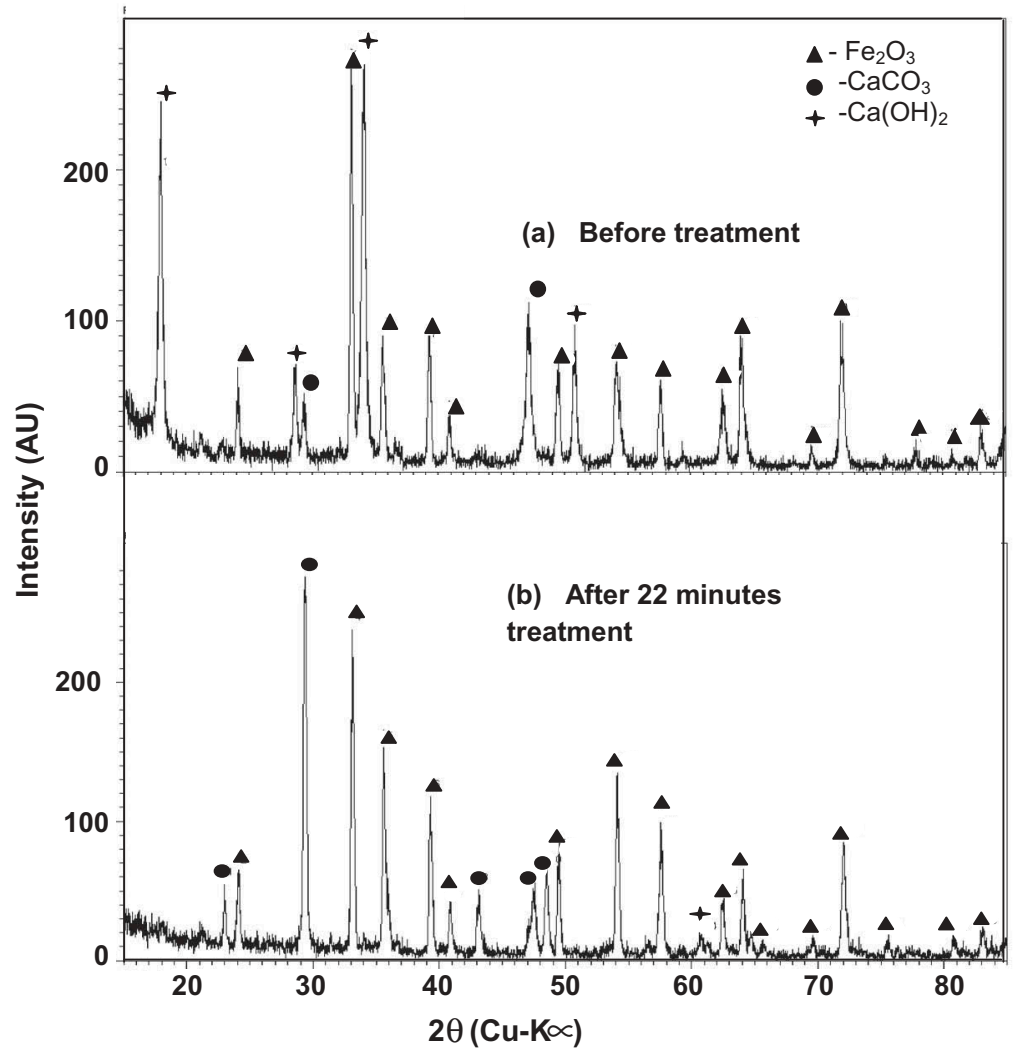

Figure 2. XRD pattern of pellet (FLIP) before and after $\mathrm{CO}_{2}$ treatment.

along with hematite. It indicates that almost the entire lime has converted to carbonate. The optical microstructure in Figure 3 (Pal et al. 2009a) shows the distribution of the hematite particles, $\mathrm{CaCO}_{3}$, and pores. The calcium carbonate formation imparts good strength to the pellet. The molar volumes (Perry and Chilton 1973) of $\mathrm{CaCO}_{3}$ and $\mathrm{Ca}(\mathrm{OH})_{2}$ are $34.10 \mathrm{~cm}^{3} / \mathrm{mole}$ and $33.59 \mathrm{~cm}^{3} /$ mole, respectively. In Reaction (2), one mole of $\mathrm{CaCO}_{3}$ is produced from one mole of $\mathrm{Ca}(\mathrm{OH})_{2}$. Thus, this transformation yields $1.52 \%$ volume expansion for lime. This volume expansion helps pellet to decrease the porosity and increase in the compactness. Thus, the transformation of $\mathrm{Ca}$ $(\mathrm{OH})_{2}$ to $\mathrm{CaCO}_{3}$ plays a predominant role for strength development of the pellets (Pal et al. 2009a, 2010).

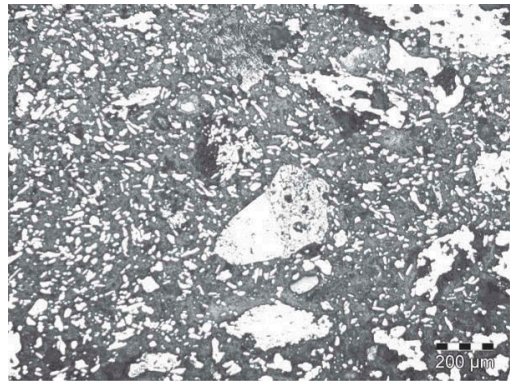

(a)
Cold crushing strength (CCS) of FLIP after $\mathrm{CO}_{2}$ treatment for varying lime content and duration of treatment is shown in Figure 4 (Pal et al. 2009a). It is obvious from the figure that $25 \%$ lime with $15 \mathrm{~min}$ of treatment time shows maximum CCS and beyond 25\% lime, the CCS again deteriorates, because excessive $\mathrm{CaCO}_{3}$ formation can develop internal stress and micro-cracks. XRD pattern (Figure 2) shows calcium hydroxide and hematite before treatment and mainly calcium carbonate and hematite with minor quantity of calcium hydroxide after treatment. This reveals that after $\mathrm{CO}_{2}$ gas treatment for $22 \mathrm{~min}$ some $\mathrm{Ca}(\mathrm{OH})_{2}$ is retained. The quantity of retained $\mathrm{Ca}(\mathrm{OH})_{2}$ is measured by weight loss analysis at different temperature and presented in Figure 5

1- Iron ore particle, 2- $\mathrm{Lime}\left(\mathrm{CaCO}_{3} / \mathrm{Ca}(\mathrm{OH})_{2}\right.$ 3- Pore

Figure 3. Optical microstructure of untreated and $\mathrm{CO}_{2}$ treated $(15 \mathrm{~min})$ pellet (FLIP) samples (a) Untreated, (b) $\mathrm{CO}_{2}$ treated. 


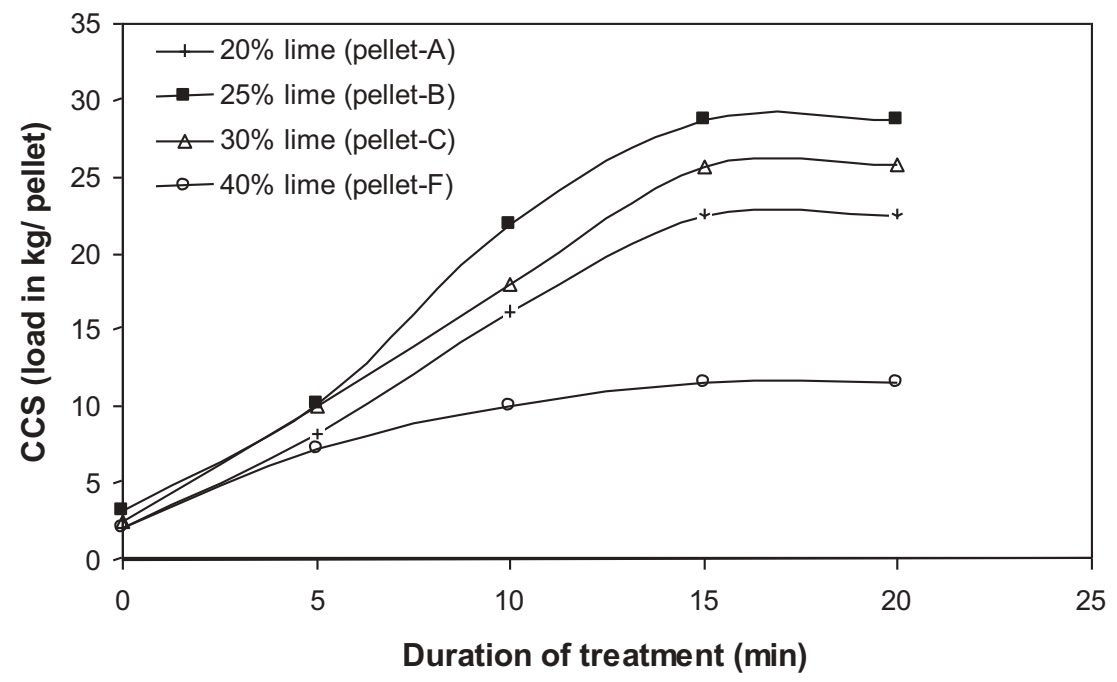

Figure 4. Effect of $\mathrm{CO}_{2}$ treatment time on CCS of pellet.

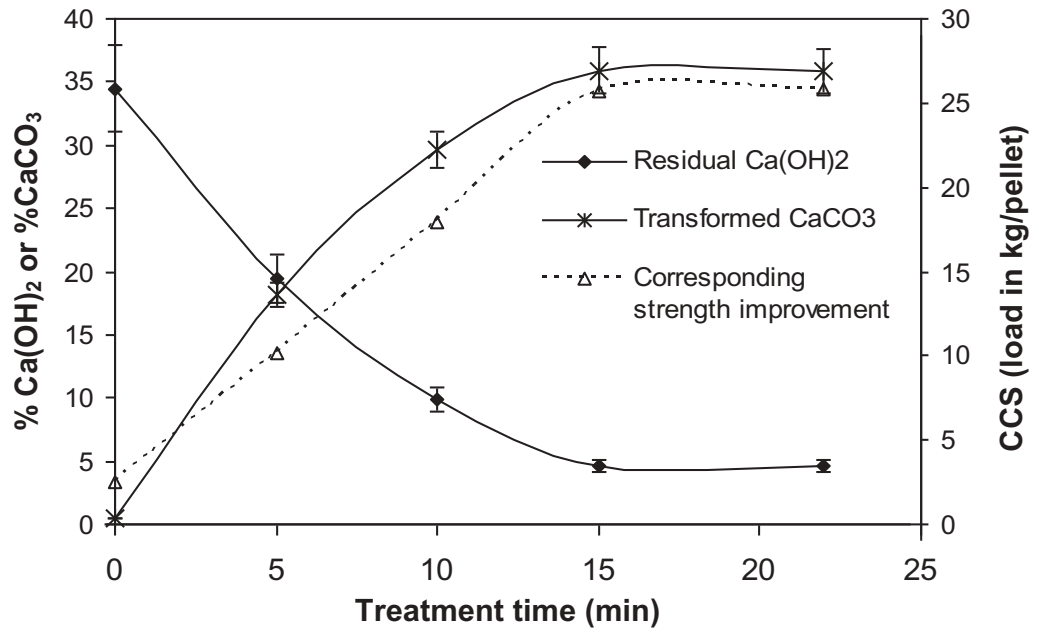

Figure 5. Amount of transformed $\mathrm{CaCO}_{3}$ and residual $\mathrm{Ca}(\mathrm{OH})_{2}$ in pellet versus treatment time.

(Pal et al. 2009a), which may be around $5 \mathrm{wt} \%$ after $15 \mathrm{~min}$ treatment. Thus, $\mathrm{CO}_{2}$ treated cold bonded fluxed lime pellet has been prepared which has a finely mixed structure of iron oxide and carbonate. It has very good strength properties.

It has been reported (Pal et al. 2009a) that very high free moisture in green pellet provides hindrance to the passage of $\mathrm{CO}_{2}$ gas entering in the pellet and makes the reaction very slow. On the other hand, a very dry pellet is not prone to react with $\mathrm{CO}_{2}$ gas. The maximum reaction has been found when free moisture in the pellet is between 1.5 and $2 \mathrm{wt} \%$. Dry slaked lime $\left(\mathrm{Ca}(\mathrm{OH})_{2}\right)$ does not absorb carbon dioxide unless a trace of moisture is present (Parkes 1961). Thus, the presence of a small amount of moisture appears to catalyze the $\mathrm{CO}_{2}$ absorption process. Possibly, the free moisture present in the pellet first reacts with $\mathrm{CO}_{2}$ gas to form carbonic acid that subsequently reacts with $\mathrm{Ca}(\mathrm{OH})_{2}$ to form $\mathrm{CaCO}_{3}$ as per the reactions in Equations (3) and (4).

$$
\mathrm{H}_{2} \mathrm{O}+\mathrm{CO}_{2}=\mathrm{H}_{2} \mathrm{CO}_{3}
$$

$$
\mathrm{Ca}(\mathrm{OH})_{2}+\mathrm{H}_{2} \mathrm{CO}_{3}=\mathrm{CaCO}_{3}+2 \mathrm{H}_{2} \mathrm{O}
$$

Further, the above reaction (Equation 2) generates a lot of exothermic heat which helps in the removal of uncombined moisture produced from the reactions in Equations (2) or (4). Thus, the pellets become dry. Here, instead of pure $\mathrm{CO}_{2}$, waste gases from steel plant containing $\mathrm{CO}_{2}$ (viz. blast furnace off gas) may also be used, which is obvious from Figure 6 (Pal et al. 2009a).

It can be mentioned that $\mathrm{CO}_{2}$ has also been used by many other investigators for the strength improvement in many other purposes. For example, investigators (Franklin et al. 1965) have found that alkaline earth metal oxides, in the presence of borax or non-metallic chloride, convert into carbonates by reacting with $\mathrm{CO}_{2}$ gas at room temperature and improve the strength of the iron ore pellets by cold bonding. In another study, any in-situ carbon in pellet can enhance the reduction of cold bonded pellet in direct reduced iron (DRI) production (Pal et al. 2015a). Accordingly, carbon was used in the pellet for making intimate contact with iron oxides and 


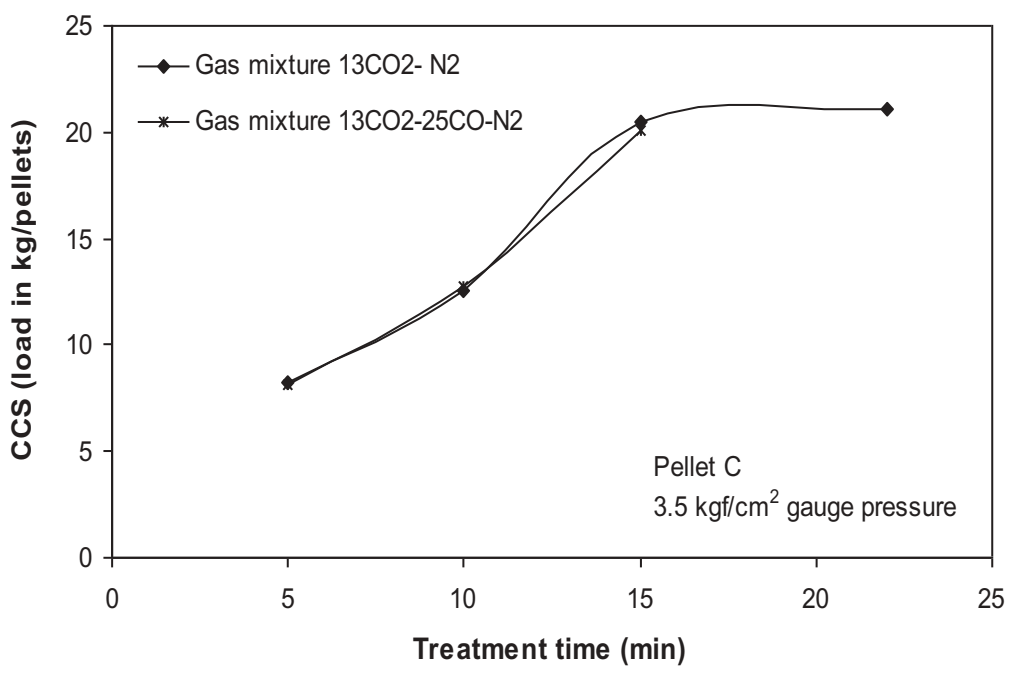

Figure 6. Effect of gas composition on the CCS of pellet at varying treatment times.

the cold bonding technology was developed to prepare coal composite pellet. Some investigators (Aota et al. 2006) used Alumina cement as a binder to obtain a high mechanical strength even at elevated temperatures. For the same purpose, carbon composite pellets with cement binding were produced by $\mathrm{CO}_{2}$ curing of the green pellets at room temperature (Yanaka and Ohno 1991; Pal and Venugopalan 2015) and also at $100-300^{\circ} \mathrm{C}$ (Liu 2003) and good strength was observed. The pellets developed from these processes have been used in DRI making. Fluxed pellets containing carbon were also prepared and cured using $\mathrm{CO}_{2}$ earlier (George 1968). However, only up to $5 \%$ coal could be used in these pellets.

Let us see what the other properties of the pellet are. On heating, the FLIP slowly disintegrates because of dissociation of calcium carbonate to $\mathrm{CaO}$ and $\mathrm{CO}_{2}$. However, it takes sufficient time and before that the melting of the FLIP starts. Melting point of the FLIP has been experimentally found out to be $1180^{\circ} \mathrm{C}$ ( $\mathrm{Pal}$ et al. 2009b). It dissolves very fast in the hot metal bath. Dissolution time at varying temperature is shown in Figure 7 (Pal et al. 2011), which is around $30 \mathrm{~min}$ at $1400^{\circ} \mathrm{C}$ hot metal temperature. After melting/dissolution, its slag has been analyzed by XRD and, as shown in Figure 8 (Pal et al. 2011), contains mainly Ca-iron oxide low melting slag. This may be favorable for the refining.

The performance study of FLIP in $8 \mathrm{~kg}$ scale refining bath has been carried out and the results are shown in Figures 9 and 10 (Pal et al. 2010). Both, decarburization and dephosphorization are much faster than the normal blowing practice with lump lime. This is because of basic and oxidizing slag generation at the early stage of blow. Si and Mn removal was found to be normal, slag foaming was within the control, blow time and oxygen consumption could be reduced by $15-20 \%$. Thus, FLIP has a very good application potential for faster refining of BOF bath.

\subsubsection{Coke breeze free sintering of steel plant waste}

The above process of FLIP preparation is an agglomeration process for mixture of flux materials by cold bonding

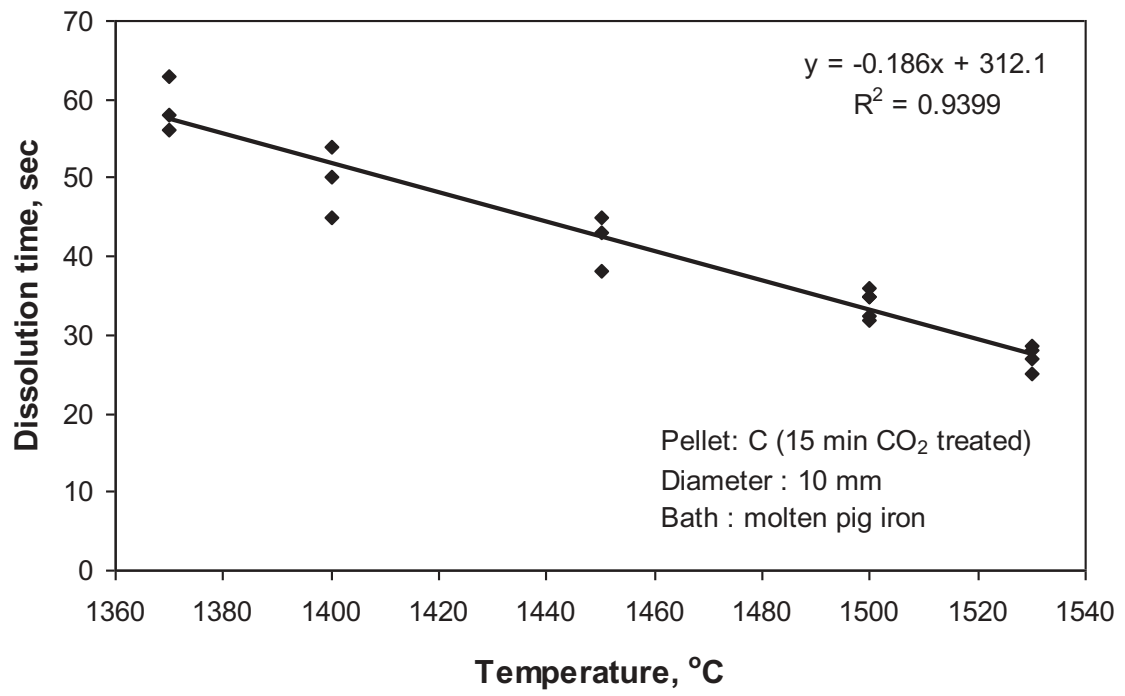

Figure 7. Effect of bath temperature on dissolution time of FLIP. 


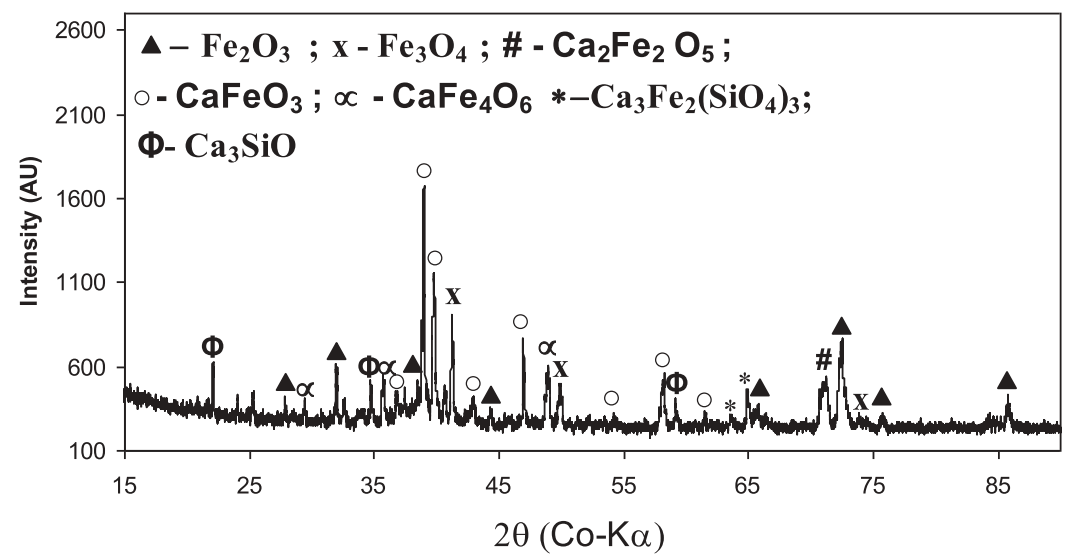

Figure 8. XRD pattern of FLIP after melting at $1245^{\circ} \mathrm{C}$.

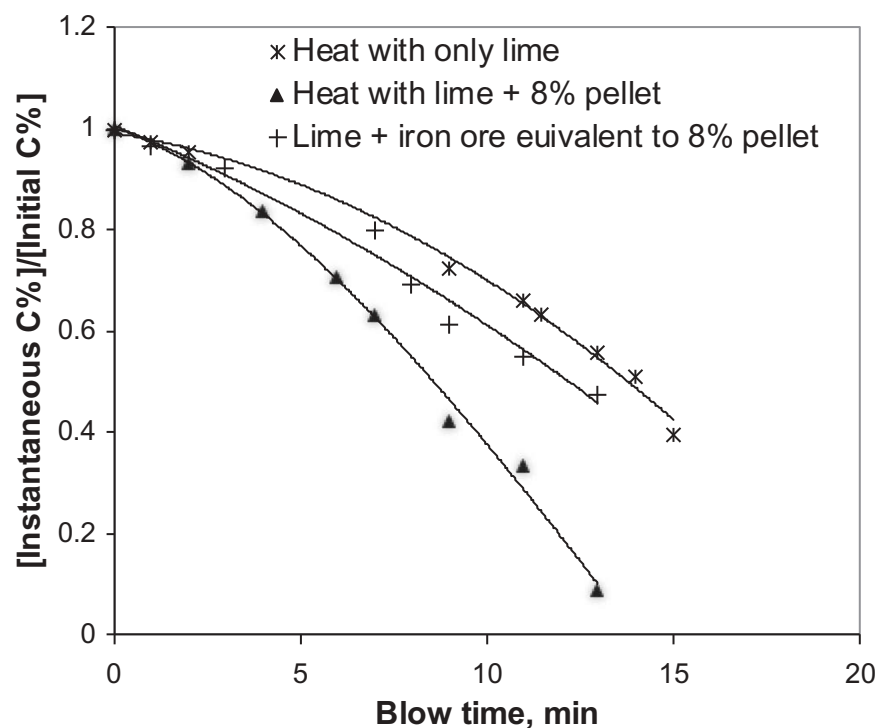

Figure 9. Performance of FLIP in decarburization of hot metal bath during oxygen blowing.

without using any costly binder. Since, there is no heating, low melting slag formation is happened when these are charged in the steel making bath. A prefused low melting flux may be more advantageous from melting and dissolution point of view which will enhance the formation of basic and oxidizing slag at the early stage of blowing. In order to develop a partially prefused synthetic flux (PSF), sintering process was adopted wherein the combination of iron oxide and lime fines and blast furnace flue dust (BFD) have been used (Pal et al. 2013a, 2013b; Pal and Venugopalan 2015). Main objective was to utilize ultrafine iron oxides wastes, such as Linz-Donawitz converter Sludge (LDS) and BFD in form of micro-pellets for developing a prefused sinter. Good binding property of calcined lime offered green bonding in the micro-pellets ( $\mathrm{Pal}$ et al. 2013a). Thus, no external binders were used. The heat of oxidation of metallic iron, wüstite, and magnetite in LDS and $\mathrm{C}$ in BFD was used to get sufficient temperature during sintering (Pal et al. 2013b) as per Equations (5)-(10) and thus avoiding the use of coke breeze in the sinter mix. The

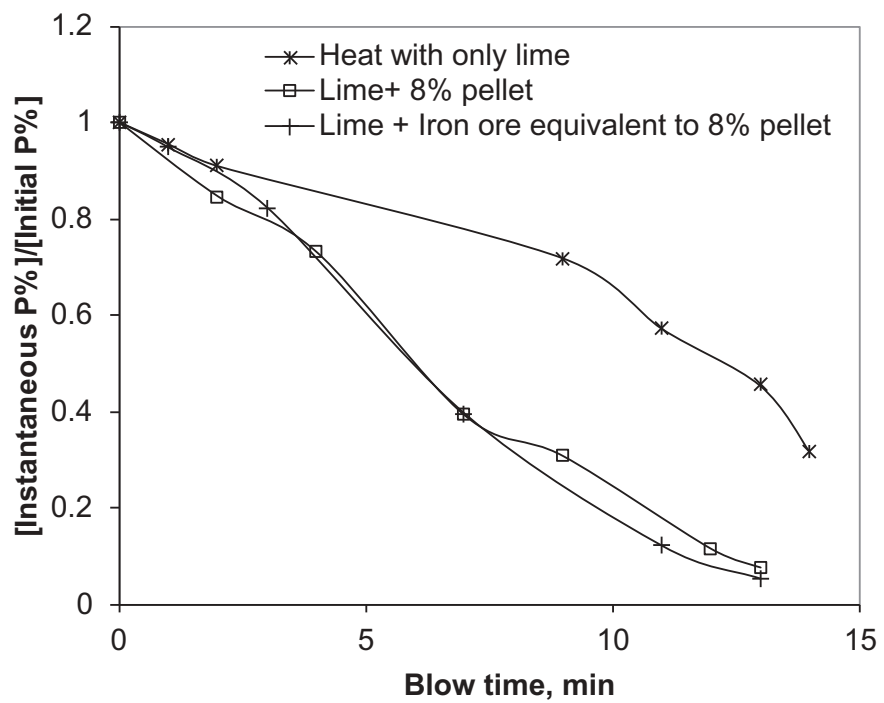

Figure 10. Performance of FLIP in dephosphorization of hot metal bath during oxygen blowing.

sinter would be a combination of Fe-oxide and $\mathrm{CaO}$ and free from combined moisture as shown in Figure 11 (Pal et al. 2013b) and termed as PSF.

$$
\begin{gathered}
\mathrm{Fe}+1 / 2 \mathrm{O}_{2}=\mathrm{FeO} ; \Delta \mathrm{H}^{0}=-266.9 \mathrm{~kJ} \mathrm{~mole}^{-1} \\
3 \mathrm{FeO}+1 / 2 \mathrm{O}_{2}=\mathrm{Fe}_{3} \mathrm{O}_{4} ; \Delta \mathrm{H}^{0}=-319.7 \mathrm{~kJ} \mathrm{~mole}^{-1} \\
2 / 3 \mathrm{Fe}_{3} \mathrm{O}_{4}+1 / 6 \mathrm{O}_{2}=\mathrm{Fe}_{2} \mathrm{O}_{3} ; \Delta \mathrm{H}^{0}=-76.4 \mathrm{~kJ} \mathrm{~mole}^{-1} \\
\mathrm{C}+1 / 2 \mathrm{O}_{2}=\mathrm{CO}(\mathrm{g}) ; \Delta \mathrm{H}^{0}=-110.5 \mathrm{~kJ} \mathrm{~mole}^{-1} \\
\mathrm{C}+\mathrm{O}_{2}=\mathrm{CO}_{2} ; \Delta \mathrm{H}^{0}=-393.5 \mathrm{~kJ} \mathrm{~mole}^{-1} \\
\mathrm{CO}+1 / 2 \mathrm{O}_{2}=\mathrm{CO}_{2} ; \Delta \mathrm{H}^{0}=-283.5 \mathrm{~kJ} \mathrm{~mole}^{-1}
\end{gathered}
$$

The chemical composition of the produced sinter was found to be $\mathrm{Fe}_{\text {total }}: 40 \%, \mathrm{CaO}: 37 \% \mathrm{SiO}_{2}: 1.5 \%, \mathrm{Al}_{2} \mathrm{O}_{3}: 1.4 \%$ and $\mathrm{Na}_{2} \mathrm{O}$ and $\mathrm{K}_{2} \mathrm{O}$ are $0.34 \%$ each and rest is oxygen combined with iron. Most of the above phases found in Figure 11 are low melting and have high $\mathrm{FeO}$ content and high basicity. From the TG-DTA study it has been found that the softening 


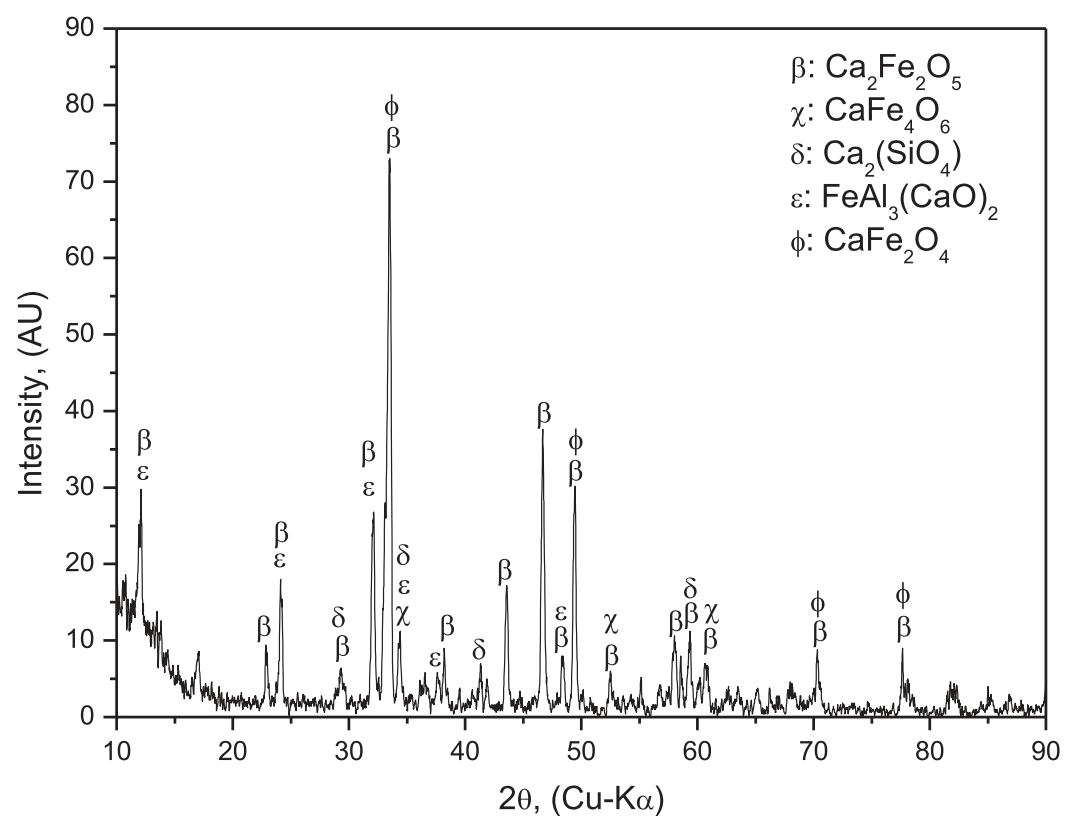

Figure 11. XRD pattern of PSF prepared.

point of sinter was $1180^{\circ} \mathrm{C}$ and melting completes at around $1280^{\circ} \mathrm{C}$.

Other physical properties like Shatter index, tumbler index, and abrasion index were found to be $90 \%, 65-70 \%$, and $8-9 \%$, respectively for $35-37 \%$ lime containing PSF (Pal et al. $2013 b)$. With further increase in lime these properties deteriorate. Furthermore, weathering property of PSF increases due to the presence of free lime in sinter beyond $37 \%$ lime. Therefore, the lime percentage was optimized at the range of 30-37 wt $\%$.

This sinter dissolves very fast in the hot metal bath as shown in Table 3 (Pal et al. 2015b). While pure lump lime not at all dissolves in the liquid bath, PSF dissolution rate is $30 \mathrm{sec} / \mathrm{g}$. This is much less than pure lime in FeO rich bath. This reveals that this flux can produce basic oxidizing slag at the early stage of blow and improve the refining process.

Refining study in $8 \mathrm{~kg}$ bottom blowing facility has been carried out to assess the performance of PSF. In Figures 12 and 13 (Pal et al. 2015b), the refining results are compared with only lime fluxed heat and lime plus iron ore fluxed heat.

Performance of PSF in refining of hot metal shows faster removal of $\mathrm{C}$ and $\mathrm{P}$ because of formation of low melting basic and oxidizing slag at the initial stage of blow. The blow time and oxygen consumption was reduced to around $40 \%$ and slag foaming was decreased. The refining process

Table 3. Dissolution time of different PSF and pure lump lime in hot metal bath at $1400^{\circ} \mathrm{C}$.

\begin{tabular}{|c|c|c|c|}
\hline Material & $\begin{array}{l}\text { Weight of } \\
\text { lump, } \mathrm{g}\end{array}$ & $\begin{array}{l}\text { Dissolution } \\
\text { time, sec }\end{array}$ & $\begin{array}{c}\text { Specific dissolution } \\
\text { time }(\mathrm{Sec} / \mathrm{g})\end{array}$ \\
\hline $\begin{array}{l}\text { Pure lump lime in } \\
\text { hot metal }\end{array}$ & 0.5034 & $\begin{array}{c}\text { Does not } \\
\text { dissolve/melt }\end{array}$ & - \\
\hline $\begin{array}{l}\text { Pure lump lime in } \\
\text { FeO rich slag }\end{array}$ & 0.5132 & 75 & 146 \\
\hline $\begin{array}{l}\text { PSF (contained } 35 \% \\
\quad \text { lime) }\end{array}$ & 1.467 & 44 & 30 \\
\hline
\end{tabular}

is much faster than FLIP charging also. Thus, the developed PSF can be used as a flux material in BOF with full replacement of iron ore and partial replacement of lump lime.

\subsection{Development of pelletizing practice to improve pellet quality}

Pelletizing of iron ore is a very well known and technocommercially established agglomeration process. In many steel plants, pellets are used in blast furnace to replace lump ore and sinters partially. It is also used in direct reduced iron (DRI) making in rotary kiln and vertical shaft. Maintaining the quality of pellets and subsequent improvement is required to increase productivity, decrease energy consumption, and using lean ores and micro-fines.

\subsubsection{Replacement of bentonite in iron ore pellet}

Bentonite is universally used as binder for green pellet making. However, due to its high alumina and silica content, it proportionally increases $\mathrm{Al}_{2} \mathrm{O}_{3}$ and $\mathrm{SiO}_{2}$ content of pellet. Finally, it increases the slag volume in downstream process of blast furnace iron making and increases the energy consumption. Moreover, the bentonite is a costly binder. Therefore, its replacement is required with a cheaper binder which has lower alumina and silica content. This may be either organic binder or inorganic binder. Eisele and Kawatra (2003) have reviewed on the several binders used so far. They have reported that apart from bentonite, the use of a numerous types of alternative binders such as starch, dextrin, Peridur, lignin, molasses, sodium silicate, fly ash, quick lime, cement etc. have been tried out worldwide. However, bentonite is considered to be the most suitable binder for iron ore pelletizing. The binding mechanism of bentonite in iron ore pellets has been studied by Kawatra and Ripke (2003a). Its effectiveness of 


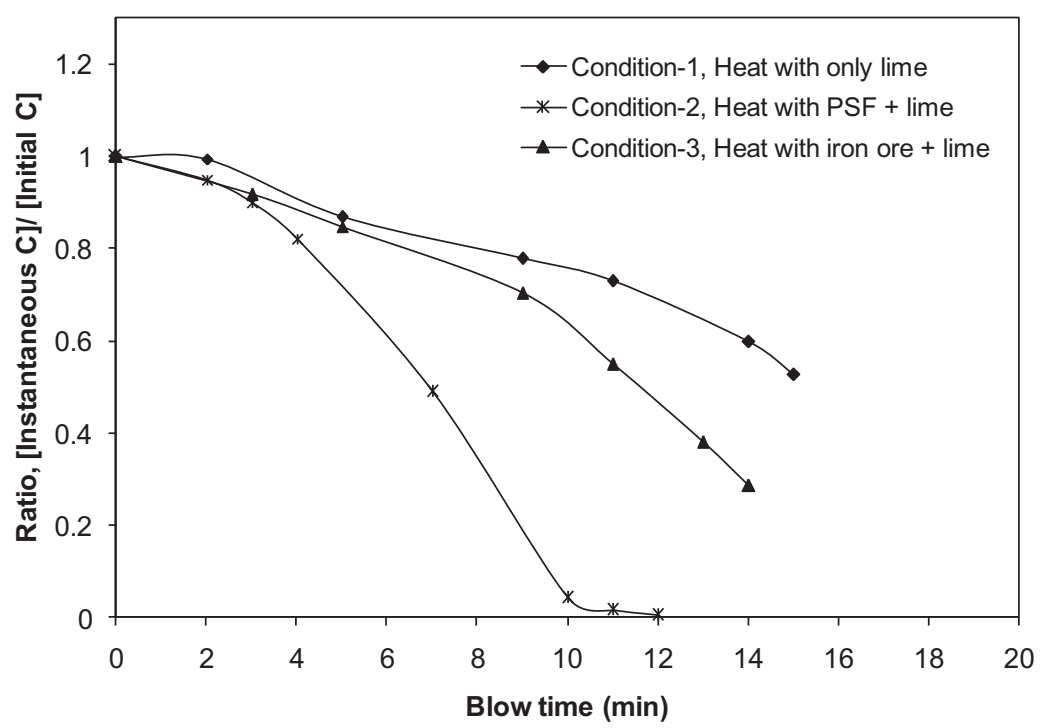

Figure 12. Performance of PSF in decarburization of hot metal bath during oxygen blowing.

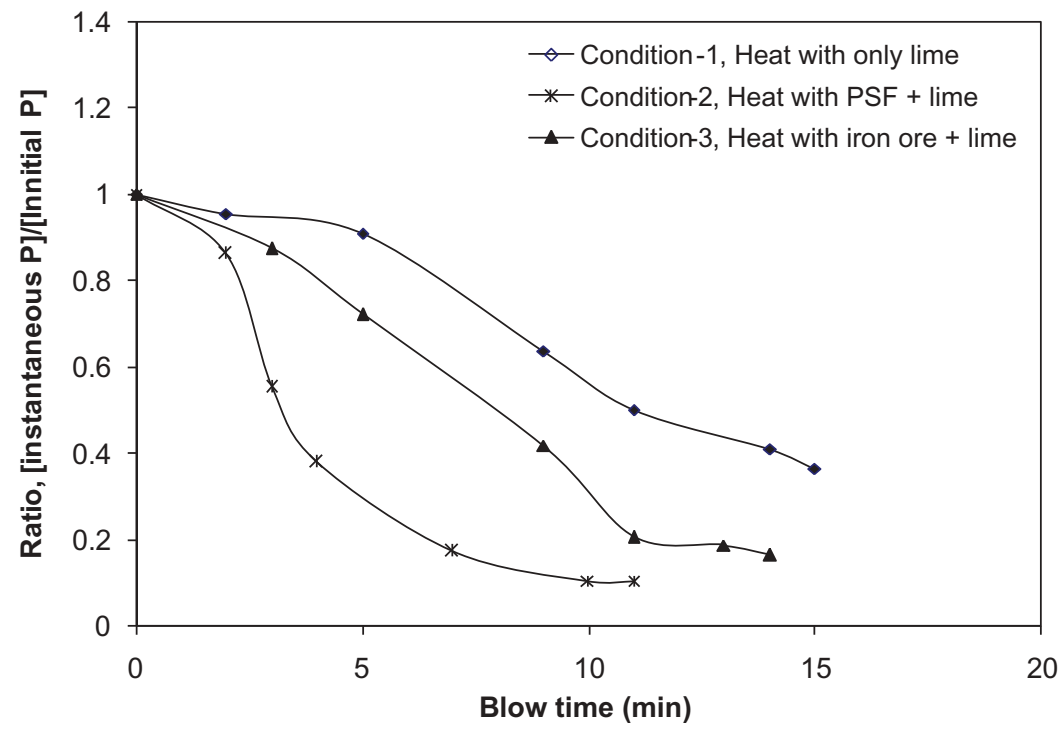

Figure 13. Performance of PSF in dephophorization of hot metal bath during oxygen blowing.

bonding has also been studied by measuring plate water absorption (Kawatra and Ripke 2003b).

Many investigators have used organic binders. Bitumen, a by-product of mineral oil processing, was found to improve green and dry compressive strength of pellet (Meyer 1980; Ansari et al., 1984). Sastry et al. (1985) reported cellulose derived organic binder, 'Peridur' as effective binder for pelletizing of iron ore. Srivastava et al. (Srivastava et al. 2013) also found good properties of iron ore pellets using $0.1 \%$ peridur. Shivaramakrishna et al. (1990) reported that starch-based binder could be used without any treatment to make cold bonded ore-coal pellet for using in DRI production but did not mention for blast furnace quality pellet making. Polyacrylamide wetted by water molecules formed long molecular chains and provided strength in pellet. However, when the pellets were heated to $105^{\circ} \mathrm{C}$, organic binder burnt out or evaporated resulting a highly porous pellet (Chizhikova and
Vainshtein 2003). Organic binders viz. starch, dextrin, and alginate found to provide good green drop number and dry compressive strength but they failed to improve the strength in the region of high temperature because, these additives were burnt off before commencing recrystallization due to which widespread application in production of fired pellet have not been found (Ball et al. 1973).

The organic binders, hemicellulose, sodium lignosulphonate, and lactose monohydrate were also able to provide good green as well as strong indurated pellets. Only $0.5 \%$ lignosulphonate has been found to be sufficient in developing required strength (Haas et al. 1989). Srivastava et al. (2013) also used sodium lignosulphonate (NLS), an extract from paper mill waste and compared with a series of organic binders in magnetite concentrate pellet. Use of lignosulphonate salt had also been examined under the scheme of novel binder development (US patent 4659374) and an encouraging result had been observed (Alanko and Atwell 1987). 
From the above it is evident that organic binders may have a potential to use in iron ore pellet making. Organic binder does not contain any significant alumina and silica. However, during drying and induration in strand, the temperature of green pellets gradually increases. Organic binders gradually evaporate and completely disappear at certain temperature $\left(600-700^{\circ} \mathrm{C}\right)$. Accordingly, organic binder loses its strength properties and pellets become less compact/weak. Coppersmelting slag (Cu-SS) has been used for this purpose as it contains a considerable amount of iron oxides (mainly $\mathrm{FeO}$ ). $\mathrm{FeO}$ and $\mathrm{Fe}_{2} \mathrm{O}_{3}$ present in $\mathrm{Cu}-\mathrm{SS}$ oxidize in induration atmosphere and provide diffusion bond above $500^{\circ} \mathrm{C}$ that maintains the strength of the pellet during drying in spite of the evaporation of NLS. Therefore, NLS provide green and dry strength and $\mathrm{Cu}$-SS provide dry strength above $500^{\circ} \mathrm{C}$ (Ammasi and Pal 2016).

In conventional practice, limestone $\left(\mathrm{CaCO}_{3}\right.$ mineral $)$ is used as $\mathrm{CaO}$ input in pelletizing. However, lime stone fines have so poor green bonding property that it is inferior to iron ore fines too. Thus, it calls for using bentonite as binder. Burnt lime contains $>90 \% \mathrm{CaO}, 1-3 \% \mathrm{SiO}_{2}$, and $\mathrm{Al}_{2} \mathrm{O}_{3}$ each with other minor impurities. When it comes in contact with water, it forms $\mathrm{Ca}(\mathrm{OH})_{2}$ and disintegrates into very fine form. Due to this fineness it shows excellent green binding properties. Therefore, researchers have used this for replacing bentonite either partially or fully.

De Sauja (De Souza 1976) has used hydrated lime in pelletizing and reported to achieve good cold crushing strength (CCS: $367 \mathrm{~kg}$ ), swelling index (18.5\%) and reducibility index $(69 \%)$ of indurated pellets. Eisele and Kawatra (2003) have also found very high green compressive strength (4 kg/pellet), drop numbers (10.4), and dry compressive strength using hydroxide lime. However, some investigators (Sarkar et al. 2013) have observed severe cracking in green and dry pellets for using hydroxide lime due to the loss of plasticity on the use of high amount of hydrated lime. Holley (1985) has also found disintegration of green pellets due to the hydration of lime resulting in expansion. Therefore, the complete hydration of lime is required before making green pellet, because, hydration of calcined lime after making the pellet may form cracks or crumbling the pellets into fines. Other investigators (Anon 2013) have also observed the similar phenomena. Furthermore, when the calcium hydroxide is mixed with bentonite, it may decrease the efficiency of bentonite as a binder. This is because it replaces the more efficient sodium ion $(\mathrm{Na}+)$ with calcium ion $\left(\mathrm{Ca}^{2+}\right)$ in the interlayer of bentonite and converts it to the more calcic and less efficient one, resulting in the deterioration of the pellet properties (Ahmed and Mohamed 2005; Fan et al. 2010; Pal et al. 2014a).

It is obvious from the above reported literature that calcined lime or hydrated lime has enough potential to provide good bonding in green pellets. However, due to the crack formation tendency and some other disadvantages, this is not widely used in the plant practice, presently. These problems are may be due to the improper operating parameters (making technique, induration temperature etc.) causing incomplete hydration before pelletizing as well as unfavorable basicity or other undesired composition of the pellets. Furthermore, high alumina hematite pellets shows very high
RDI (Pal et al. 2015c) and a suitable quantity of $\mathrm{MgO}$ addition may also solve these problems. Thus, the pellet chemistry and making parameters have to be optimized to prepare good quality calcined lime pellet without bentonite. Moreover, some investigators as mentioned above have used bentonite also with the calcined lime, but it deteriorates the quality of bentonite as discussed in the previous section. Since calcined lime has very good bonding property, it is imperative to develop a suitable technology, which can eliminate the above problems. It will help in reducing silica and alumina load in the pellets and in the downstream process of blast furnace iron making.

In the recent study (Pal et al. 2014a) first, several parameters ( $\mathrm{MgO}$ content, basicity, fineness etc) have been optimized using olivine as $\mathrm{MgO}$ source and limestone as $\mathrm{CaO}$ source and bentonite as binder. Subsequently, the pellets were prepared with calcined lime or hydrated lime as per optimized conditions of basicity and wt $\%$ of $\mathrm{MgO}$ replacing the bentonite fully. Some of the important results are presented as follows (Pal et al. 2014a).

The green pellet properties of calcined lime pellet without bentonite and lime stone plus bentonite added pellets are shown in Table 4 (Pal et al. 2014a). The GCS and drop numbers of calcined lime added pellets are much higher than bentonite added pellet because of the good green bonding property of calcined lime. Dry compressive strength is relatively lower than bentonite added pellet but, it is well above the acceptable limit. Now on heating during drying the moisture combined with hydrated lime starts to evaporate at and above $400^{\circ} \mathrm{C}$. Therefore, there is a chance of decreasing the strength of calcined lime pellet. To assess its strength and stability during drying, the pellets were heated at $800^{\circ} \mathrm{C}$ in a chamber furnace and CCS was measured which were found to be $6.5 \mathrm{~kg} /$ pellet and $3 \mathrm{~kg} /$ pellet for bentonite added pellet and calcined lime pellets, respectively. It loses the strength at drying temperature. However, the load test at hot condition was done in a chamber furnace at $900^{\circ} \mathrm{C}$ (Figure 14) (Pal et al. 2014a), which confirms its stability during drying.

Other metallurgical properties of calcined lime pellets are comparable with the limestone plus bentonite added pellets as shown in Table 5 (Pal et al. 2014a). Silica and alumina content of calcined lime added pellet (Table 6) (Pal et al. 2014a) has been found to be lower than the limestone plus bentonite added pellet, which will be beneficial in blast furnace iron making. In brief, the calcined lime can provide better green pellets properties as well as desired strength at high temperature without any bentonite addition. It also provides required basicity to the pellet. Thus, both limestone and bentonite can be replaced in pellet and hence alumina and silica load will be

Table 4. Green and dry pellets properties of calcined lime and limestone plus bentonite added pellets.

\begin{tabular}{lccccccc}
\hline $\begin{array}{l}\text { Lime flux } \\
\text { added }\end{array}$ & Basicity & $\begin{array}{c}\text { Moisture } \\
\%\end{array}$ & $\begin{array}{c}\text { MgO } \\
\%\end{array}$ & $\begin{array}{c}\text { Bentonite } \\
\%\end{array}$ & $\begin{array}{c}\text { GCS, } \\
\mathrm{kg} / \\
\text { pellet }\end{array}$ & $\begin{array}{c}\text { Green } \\
\text { drop } \\
\text { No }\end{array}$ & $\begin{array}{c}\text { DCS } \\
\mathrm{kg} / \\
\text { pellet }\end{array}$ \\
\hline $\begin{array}{c}\text { Limestone: } \\
0.95 \%\end{array}$ & 0.25 & 8.5 & 1.0 & 0.3 & 1.3 & 9 & 5.5 \\
$\begin{array}{c}\text { Calcined } \\
\text { lime: }\end{array}$ & 0.25 & 8.8 & 1.0 & Nil & 1.5 & 12 & 3.5 \\
$0.45 \%$ & & & & & & & \\
\hline
\end{tabular}




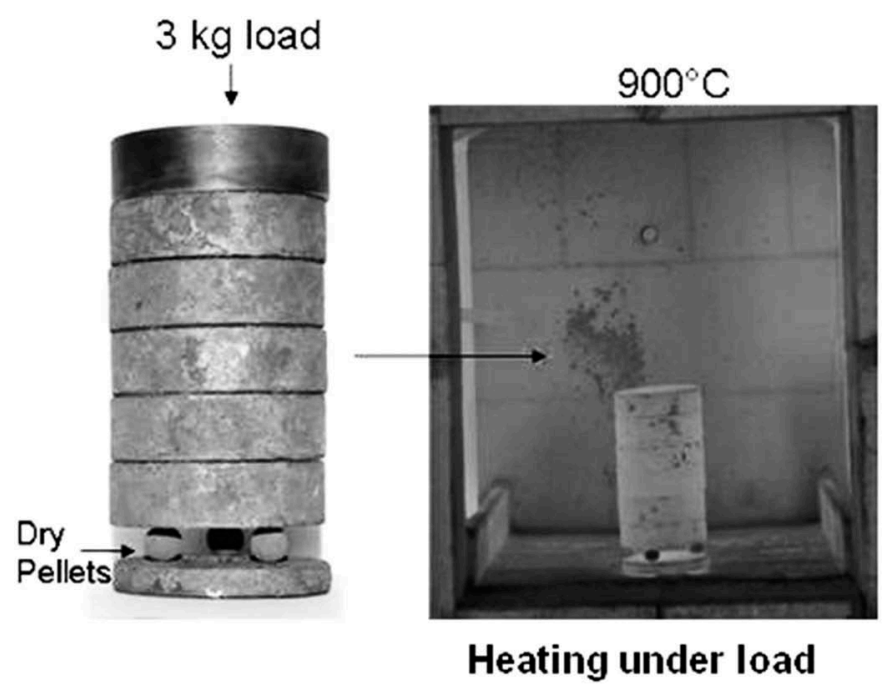

Figure 14. Photograph of calcined lime fluxed pellets during heating under load.

reduced. Thus, it is advisable to use calcined lime in pellet making that is available from the lime calcinations plant in almost all integrated steel plant.

\subsubsection{Improving reducibility of hematite ore pellet}

Reducibility of pellet is an important property. Pellet with good reducibility can improve the indirect reduction in blast furnace and reduces the energy consumption. Though, pellet generally has better reducibility than lump ore and sinter due to its micro-porosity, it depends upon several parameters viz, chemistry, physical structure, induration temperature, shapes etc. Many researchers have tried to improve the reducibility of pellets.

A dolomite (Bin et al. 2013) and other MgO-bearing materials such as olivine, magnesite ( $\mathrm{Pal}$ et al. 2015d; Md. et al. 2016) and serpentine were effectively used as basic fluxing materials to improve both reducibility and reduction degradation index. During induration of $\mathrm{MgO}$ containing iron oxides, $\mathrm{MgO}$ diffuses in the $\mathrm{Fe}_{2} \mathrm{O}_{3}$ lattice forming magnesio-ferrite $\left(\mathrm{MgO} \mathrm{Fe}_{2} \mathrm{O}_{3}\right)$ spinel (melting point $\left.1713^{\circ} \mathrm{C}\right)$. The magnesioferrite in the fired pellets improves their strength during reduction and increases the softening temperature. Porosity, pore volume and pore diameter in pellet also increases in presence of $\mathrm{MgO}$ in pellet (Bin et al. 2013). Nasr et al. (1995) studied on the reduction of $\mathrm{NiO}$ doped hematite compacts wherein, the reduction rate was gradually increased with the increase in reduction temperature and $\mathrm{NiO}$ content due to the formation of more porous compound, $\mathrm{NiFe}_{2} \mathrm{O}_{4}$ that is more reducible than iron oxide. Botelho et al. (2014) developed a process of improving reducibility of iron ore by adding metallic Ni containing materials because the metallic Ni provides the catalytic effect for the reduction. Presence of $\mathrm{Cr}^{3+}$
Table 6. Chemical analysis of limestone added and calcined lime added indurated pellets.

\begin{tabular}{lccccccc}
\hline Pellets & $\begin{array}{r}\text { Bentonite } \\
\text { added, } \%\end{array}$ & $\begin{array}{c}\mathrm{Fe}_{\text {total, }} \% \\
\%\end{array}$ & $\begin{array}{c}\mathrm{CaO}, \\
\%\end{array}$ & $\begin{array}{c}\mathrm{SiO}_{2}, \\
\%\end{array}$ & $\begin{array}{c}\mathrm{Al}_{2} \mathrm{O}_{3}, \\
\%\end{array}$ & $\begin{array}{c}\mathrm{MgO}, \\
\%\end{array}$ & Basicity \\
\hline $\begin{array}{c}\text { Limestone plus } \\
\text { bentonite } \\
\text { added }\end{array}$ & 0.3 & 65.1 & 0.64 & 2.59 & 2.57 & 1.04 & 0.247 \\
$\begin{array}{c}\text { Calcined lime } \\
\text { added }\end{array}$ & 0 & 65.5 & 0.61 & 2.41 & 2.51 & 1.02 & 0.253 \\
\hline
\end{tabular}

also increases the reducibility of iron oxide by $\mathrm{CO}$ due to catalytic effect of partially filled d-band and unpaired election (Sarangi and Sarangi 2011).

Investigators have tried to improve the reducibility by changing different parameters mainly through the change in chemistry and phase formation by different additives and fluxes. However, in our study reducibility index (RI) of hematite ore pellet has been increased with respect to the current level at the plant (Tata Steel, India) (Pal et al. 2017b). However, other properties were maintained in the acceptable limit. This has been done by optimizing the physical parameters of pelletizing such as induration temperature, size distribution of fines, and improving apparent porosity without changing any chemistry of green pellets or additives ( $\mathrm{Pal}$ et al. 2017b). The effect of induration temperature on reducibility of iron ore pellet is shown in Figure 15 ( $\mathrm{Pal}$ et al. 2017b) that it decreases with increasing induration temperature. However, too much decrease in induration temperature may hamper the strength and other properties of pellet. Therefore, an optimization study has been carried out. Optimum values of parameters have been found as induration temperature: $1275^{\circ} \mathrm{C}$, lime stone size: below 350 mesh, coal size: below $350 \mathrm{mesh}$, for the iron ore Blaine fineness of $2855 \mathrm{~cm}^{2} / \mathrm{g}$. The properties of pellets with these optimized values are shown in Table 7 (Pal et al. 2017b). It is obvious from the table that reducibility index (RI) could be improved by $7-8 \%$ point and other properties viz. CCS, reduction degradation index (RDI) and swelling index has also been improved. Tata Steel now uses around $1275^{\circ} \mathrm{C}$ induration temperature and $2700-2900 \mathrm{~cm}^{2} / \mathrm{g}$ Blaine fineness.

\subsubsection{Lowering reduction degradation index of hematite pellet}

Degradation of pellets during low temperature reduction is happened due to lattice distortion and internal stress generation due to hematite to magnetite transformation. This is an undesirable property of iron ore pellet. Maximum reduction degradation index (RDI) of around $20 \%$ is considered to be tolerable in blast furnace. However, most of the Indian ores and many other hematite ores contain high alumina has high RDI in their pellet. A suitable flux addition has been done by several investigators. Serpentine has been used (Wang and

Table 5. Comparison of properties of pellets with limestone plus bentonite and calcined lime.

\begin{tabular}{|c|c|c|c|c|c|c|c|}
\hline Pellets & Bentonite added, \% & $\begin{array}{c}\text { Induration } \\
\text { temperature, }{ }^{\circ} \mathrm{C}\end{array}$ & $\begin{array}{l}\text { CCS, kg/ } \\
\text { pellet }\end{array}$ & $\mathrm{Rl}, \%$ & RDI, \% of $-3.15 \mathrm{~mm}$ & Swelling Index, \% & $\begin{array}{c}\text { Apparent porosity, } \\
\%\end{array}$ \\
\hline Limestone plus bentonite added & 0.30 & 1280 & 310 & 75.5 & 11.8 & 14.7 & 22.6 \\
\hline Calcined lime added & 0 & 1280 & 312 & 74.7 & 12.1 & 14.9 & 23.54 \\
\hline
\end{tabular}




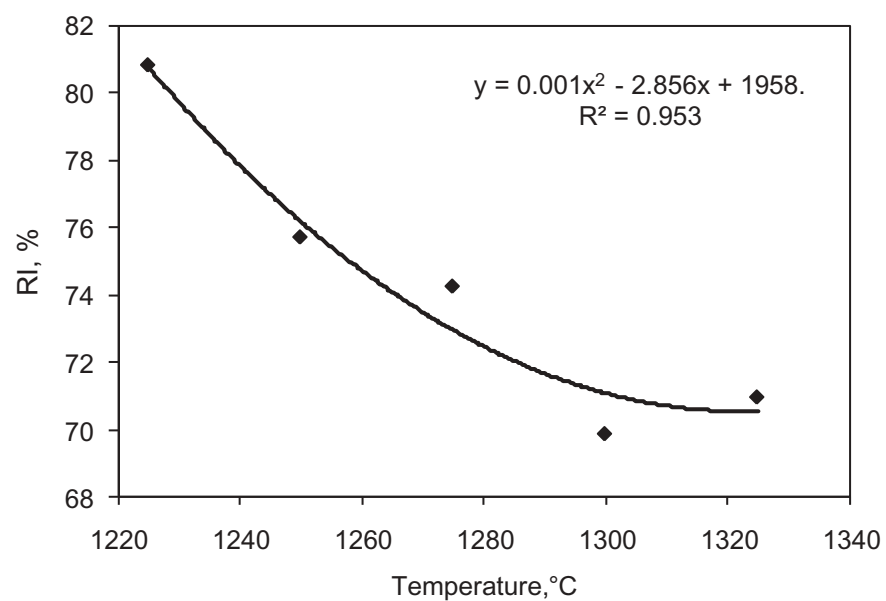

Figure 15. Effect of induration temperature on RI of pellet.

Table 7. Properties of pellets with optimized values.

\begin{tabular}{lccccccc}
\hline Pellet & $\begin{array}{c}\text { Blaine } \\
\text { No }\end{array}$ & Basicity & CCS & $\begin{array}{c}\text { Rl, } \\
\%\end{array}$ & $\begin{array}{c}\text { RDI, } \\
\%\end{array}$ & $\begin{array}{c}\text { Sl, } \\
\%\end{array}$ & $\begin{array}{c}\text { AP, } \\
\%\end{array}$ \\
\hline $\begin{array}{l}\text { Reference pellet } \\
\begin{array}{l}\text { At Optimized } \\
\quad \text { condition }\end{array}\end{array}$ & 2855 & 0.32 & 249 & 69.5 & 20 & 14.1 & 9.9 \\
\hline
\end{tabular}

Wu 2014) to reduce RDI which help in forming high melting point magnesium wustite. Olivine has also been used (Forsmoa and Hagglund 2003) in iron ore pellets to decrease DRI. However, Semberg et al. (2011) found the appearance of cracks in olivine added magnetite ore along the boundary between secondary magnetite and magnesioferrite during reduction at $600-700^{\circ} \mathrm{C}$. The similar crack formation in olivine added magnetite pellet has been found by Lingtan et al. (1983) though it improved the high temperature reducibility of pellets. The basicity of pellet has an important role in reducing the RDI of pellet. Umadevi et al. (2011) found better RDI of pellet in the range of $0.33-0.78$ than 1.5 basicity pellets. Since, high basicity pellet shows high RDI, Shigaki et al. (1990) prepared two layered pellet with relatively low basicity at the shell and high basicity with high $\mathrm{MgO}$ content at the core. As shell had lower RDI, the cracks did not propagate and overall $\mathrm{RDI}$ of the pellet was found to be decreased. $\mathrm{CaO}$ and $\mathrm{MgO}$ bearing mineral can reduce $\mathrm{RDI}$ to a great extent (Gao et al. 2014; Md. et al. 2016). However, the scope of flux addition is not always available. Moreover, added flux can effect on many other properties such as reducibility, porosity etc. of pellet. Apart from the flux addition, if carbon is added in pellets, some hematite in pellet reduces to magnetite during induration (Pal and Venugopalan 2015). This magnetite formation helps to reduce RDI. However, Umadevi et al. (2008) and Umadevi et al. (2013)) reported that the reduction of RDI with addition of coke breeze is limited up to a certain carbon level after that RDI again increases with increase in carbon.

RDI of iron ore sinter has been reduced by salt solution treatment (Taguchi et al. 1990; Larrea et al. 1998; Xu et al. 2010). This technique of treatment has been used on reduction of RDI in iron ore pellet as iron ore pellets also have micro-pores. The study has been carried out to identify the effect of varying concentration of several salt solutions such as, $\mathrm{CaO}, \mathrm{MgO}, \mathrm{MgCl}_{2}, \mathrm{CaCl}_{2}$ and $\mathrm{NaCl}$ of under vacuum (45 $\mathrm{mm} \mathrm{Hg}$ ) to reduce RDI and their optimum levels has been investigated (Ranjan and Pal 2016).

Treatment of hematite pellets with $\mathrm{CaO}$ and $\mathrm{MgO}$ solution does not show any reduction in RDI of pellet as these oxides have very low solubility in water. Among all these salts $\mathrm{NaCl}$ showed best performance on reduction in RDI. It is envisaged from the Figure 16 (Ranjan and Pal 2016) that with increase in concentration of $\mathrm{NaCl}$ solution, $\mathrm{RDI}$ decreases drastically from very high level (86\%) to very low level $(2.4 \%)$ only at $6 \%$ solution concentration. The apparent porosity also decreases with increase in salt concentration. The main reason of decreasing RDI would be the blockage of micro-pores and hindrance of reducing gas for the reduction at low temperature. Furthermore, conforming to $\mathrm{Xu}$ et al. (2010) $\mathrm{Cl}^{-}$ions and $\mathrm{Fe}_{2} \mathrm{O}_{3}$ in the sinter have surface reaction, which enhances the binding energy of $\mathrm{Fe}-\mathrm{O}$ band in hematite. Due to this, during low temperature reduction at $500-600^{\circ} \mathrm{C}$ it is more difficult for $\mathrm{CO}$ to despoil of $\mathrm{O}^{2-}$, which causes decrease in reduction rate (Xu et al. 2010; Ranjan and $\mathrm{Pal}$ 2016). Thus, inhibition of $\mathrm{Fe}_{2} \mathrm{O}_{3}$ to $\mathrm{Fe}_{3} \mathrm{O}_{4}$ reduction at low temperature prevents generation of stress induced cracks due to crystal transformation, which help reducing RDI (Ranjan and $\mathrm{Pal}$ 2016).

RDI has been found to be reduced by $2.5 \%$ in acidic pellet, when $6 \% \mathrm{NaCl}$ solution was used for the treatment. However, it shows high chloride input in pellet and poor degradation resistance at relatively high $\left(>800^{\circ} \mathrm{C}\right)$ temperature and breakage. In contrary, the fluxed pellet (Basicity: 0.25 ), treated with only $2 \% \mathrm{NaCl}$ solution under vacuum, showed very low RDI (6\%). This pellet does not show any breakage during reduction at relatively high $\left(>800^{\circ} \mathrm{C}\right)$ temperature. Thus, the fluxed pellets with only 0.25 basicity treated with only $1-2 \% \mathrm{NaCl}$ solution at room temperature under vacuum have very low RDI (6-10\%) with good CCS (330 kg/pellet), reducibility (75\%) and swelling index (13\%)(Ranjan and Pal 2016). Such pellets are likely to be useful for blast furnace iron making.

\subsection{Innovation in sintering for increasing use of micro- fines}

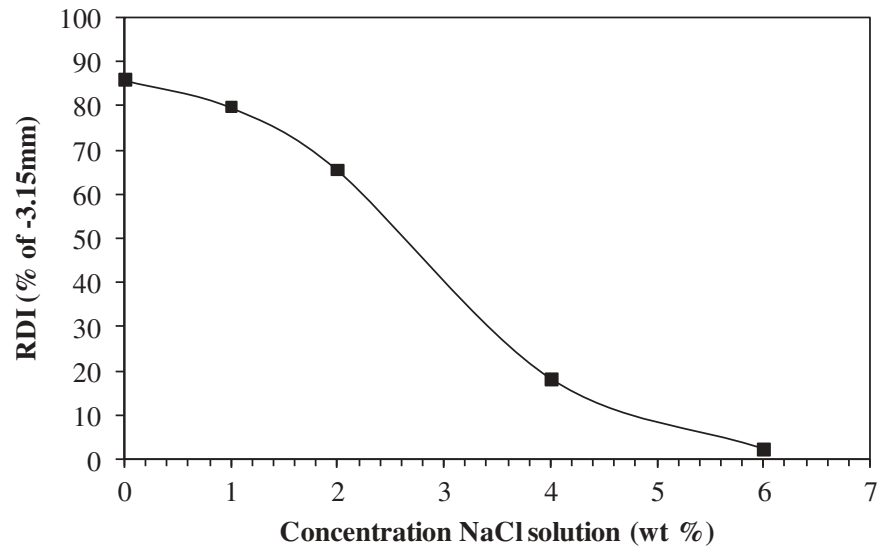

Figure 16. Effect of $\mathrm{NaCl}$ solution on reduction of $\mathrm{RDI}$ in acidic pellet. 
Conventional sintering process for iron ore has limitation of accepting micro-fines, because it affects on the permeability of the sinter bed and decrease productivity and deteriorates the quality. Therefore, a suitable technology needs to be developed to increase the fine acceptability of sinter bed.

\subsubsection{Micropelletizing and sintering of iron ore micro-fines}

Micro-fines (below 100 mesh) has been micro pelletized by several investigators and mixed the micro-pellets with normal sinter mix. Several investigators (Anon 1997; Nakano et al. 2000; Chaudhary et al. 2001) prepared micro-pellets of these fines and produced BF grade sinter. However, sufficient cold handling strength of these micro-pellets is required to minimize fines generation during their transportation, handling in granulation drum and charging in sinter strand. Further, the strength is also necessary to withstand the load of sinter bed during sintering. Several investigators (Rankin and Rolloer 1985) have explored microfines utilization in the sintering bed by pre-balling the green mix in presence of water in the secondary drum before charging in the bed and found a good result. The performance of pre-balling was further improved by addition of hydrated lime in sinter mix. However, they achieved only up to $30 \%$ microfines utilization. Microfines of iron ore with fluxes were pelletized into 2-6 $\mathrm{mm}$ pellets and named as 'micro-pellets' (Panigraphy et al. 1989) and used in the sinter mix. Much better utilization has been observed.

Coal composite iron oxide micro-pellets (2-6 $\mathrm{mm}$ size) were produced through an innovative technique, wherein lime and molasses were used as binding materials for micropellets (Pal et al. 2015a). The micro-pellets were subsequently treated with $\mathrm{CO}_{2}$ or industrial waste gas for chemical bond formation. At very high carbon level of $22 \mathrm{wt} \%$ (38 wt $\%$ of coal), cold crushing strength of the micro-pellets was 2.5$3 \mathrm{~kg} / \mathrm{cm}^{2}$ and abrasion index was 5-9 wt\%, which appear suitable for cold handling. These micro-pellets have a great potential for use as heat source in smelting reduction in iron making and sintering to reduce coke breeze etc. The properties of micro-pellets prepared from iron ore micro-fines with three different $\mathrm{C}$ sources viz. coal, blast furnace flue dust (BFD) and coke fines are shown in Table 8 (Pal et al. 2015a).

Since the micro-pellets prepared in this study contain carbon and have very good handling strength, they can be used in sinter bed to reduce the coke breeze consumption in sintering as well as to improve fines utilization. The feasibility test on this was carried out in a $12 \mathrm{~kg}$ scale sintering pot (Pal et al. 2015a). Here, the green sinter mix containing iron ore fines, coke breeze and fluxes were mixed with the BFD-added or coke-added micro-pellets and sintered in a $12 \mathrm{~kg}$ capacity down draft sinter pot (150 mm internal dia. and $470 \mathrm{~mm}$ long). The temperature of the sinter bed was found to be raised up to $1350^{\circ} \mathrm{C}$ (Pal et al. 2015a). The properties of produced sinter viz. sinter yield, shatter indices, and abrasion indices are found to be very good and acceptable $(65 \%, 91 \%$ and $5 \%$, respectively). It may be noted that coke breeze consumption in sintering with developed BFDadded and coke-added micropellets are 4 and $3.4 \mathrm{wt} \%$, respectively. However, in usual sintering it is $6.5 \mathrm{wt} \%$. Thus, it reduces the coke breeze consumption by $30-40$ wt $\%$ without affecting the sinter quality.
Table 8. Properties of micro-pellets prepared. Micro-pellet composition

\begin{tabular}{lcccccc}
\hline $\begin{array}{l}\text { Molasses } \\
(\text { wt\%) }\end{array}$ & $\begin{array}{c}\text { Lime } \\
\text { (wt\%) }\end{array}$ & $\begin{array}{c}\text { C-bearing } \\
\text { material (wt\%) }\end{array}$ & $\begin{array}{c}\text { Iron ore } \\
\text { conc. }\end{array}$ & $\begin{array}{c}\text { CCS, kg/ } \\
\text { pellet }\end{array}$ & $\begin{array}{c}\text { Drop } \\
\text { Nos }\end{array}$ & $\begin{array}{c}\text { Abrasion } \\
\text { index, } \% \\
(15 \mathrm{~kg} \\
\text { sample) }\end{array}$ \\
\hline 4 & 10 & Coal: 38 & Rest & 4.0 & 100 & 9.97 \\
4 & 10 & BFD: 38.7 & Rest & 4.7 & 130 & 8 \\
4 & 10 & Coke fines: 18 & Rest & 4.3 & 130 & 8.5 \\
\hline
\end{tabular}

\subsubsection{Development of pellet-sinter composite agglomerate} (P-SCA)

The burden combination with acidic pellet and super fluxed sinter can improve the utilization of fines in iron making. For the micro-fines utilization, pelletizing is a suitable route. However, it shows very high energy consumption in its induration and hardening. To avoid costly induration, hybrid pelletizing (Sakamoto et al. 1989; Pal et al. 2014b) was done for utilizing micro-fines, wherein the green pellets were coated with carbon powder and then sintered in a sinter bed to make a composite mass, called hybrid pelletized sinter (HPS). HPS may disintegrate in to individual pellets during treatment and transportation due to their inadequate contact area between fired pellets (Jiang et al. 2010). However, conforming to Niwa et al. (1993), this process has been implemented in Japan and showed improved blast furnace productivity.

The investigators (Jiang et al. 2010) have developed the composite agglomeration process (CAP), which has produced a composite mass of pellets and sinter wherein, acidic pellets were embedded in to the basic sinter mass. They found very good properties such as shatter index, tumbler index, reducibility index and reduction degradation index for magnetite pellets. They suggested using carbon in hematite pellets for heat generation in pellet and improve its strength, but the obtained strength was not reported.

National Metallurgical Laboratory (NML) has also developed composite agglomerate utilizing hematite ore wherein, in-situ heat generation in pellet was tried out with different materials viz. carbon, LD Sludge (LDS) and mill scale (Pal et al. 2014b). First, the green pellets were made from the micro-fines of -100 mesh as shown in Figure 17 (Pal et al. $2014 \mathrm{~b})$. Then it was mixed with sinter mix and the sintering was done in a pot of 10-12 kg capacity.

The good quality composite agglomerate was produced when LDS or mill scale were used as in-situ heat source in pellet. The formation of in-situ heat in pellet was happened by oxidation of metallic iron and its lower oxides ( $\mathrm{Fe}, \mathrm{FeO}$, and $\mathrm{Fe}_{3} \mathrm{O}_{4}$ present in LDS) during sintering as per reactions in Equations (11)-(14).

$$
\begin{gathered}
\mathrm{Fe}+1 / 2 \mathrm{O}_{2}=\mathrm{FeO} ; \Delta \mathrm{H}^{0}=-266.9 \mathrm{~kJ} \mathrm{~mole}^{-1} \\
3 \mathrm{FeO}+1 / 2 \mathrm{O}_{2}=\mathrm{Fe}_{3} \mathrm{O}_{4 ;} \Delta \mathrm{H}^{0}=-319.7 \mathrm{~kJ} \mathrm{~mole}^{-1} \\
2 / 3 \mathrm{Fe}_{3} \mathrm{O}_{4}+1 / 6 \mathrm{O}_{2}=\mathrm{Fe}_{2} \mathrm{O}_{3} ; \Delta \mathrm{H}^{0}=-76.4 \mathrm{~kJ} \mathrm{~mole}^{-1} \\
2 \mathrm{Fe}+3 / 2 \mathrm{O}_{2}=\mathrm{Fe}_{2} \mathrm{O}_{3} ; \Delta \mathrm{H}^{0}=-823.4 \mathrm{~kJ} \mathrm{~mole}^{-1}
\end{gathered}
$$




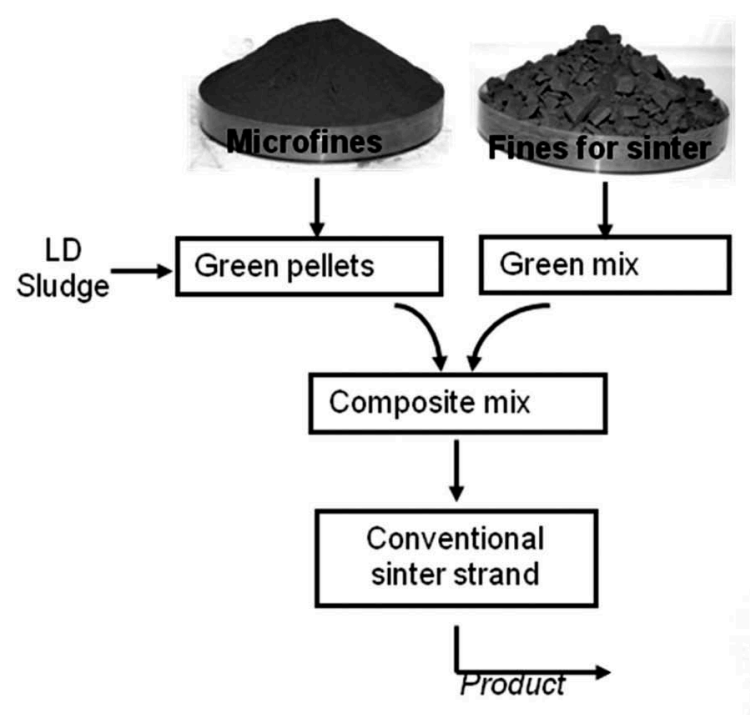

P-SCA

Figure 17. Preparation of Pellet-sinter composite agglomerate.

At the initial stage, the pellets may absorb heat from the sintering gas to reach at the elevated temperature, then the oxidation reactions (Eqs. (11-14)) become faster and a significant quantity of heat $(0.236 \mathrm{~kJ} / \mathrm{g}$ of pellet $)$ is generated inside the pellet. The in-situ heat in pellet exhibits the bond formation in pellet ( $\mathrm{Pal}$ et al. 2014b). As above reactions do not produce any gas, the bonding seemingly becomes stronger to provide good CCS in pellet. However, if $\mathrm{C}$ is used as heat source $\mathrm{CO}$ or $\mathrm{CO}_{2}$ gas formation may be happened and affect the bond formation which may weaken the pellet strength.

The properties of such P-SCA produced are shown in Table 9 (Pal et al. 2014b) and compared with usual sinter made from the same iron ore. It is obvious from the table that P-SCA has much better physical and metallurgical properties for the same $(5.1 \%)$ coke rate. For achieving the comparable property, much higher amount of coke rate is required for usual sintering. This energy consumption was reduced by $\sim 20 \%$, while around $60 \%$ micro-fines utilization was possible. Due to the lowering energy consumption and coke rate reduction $\mathrm{CO}_{2}$ emission was also reduced. Thus, the process can be considered as energy friendly.

It may be mentioned that conventional pellet charging in blast furnace may create inhomogeneous distribution when it charges with other materials in blast furnace due to its low angle of repose. However, in P-SCA no such problem is expected because, the pellets are sticked with sinter mass which have less rolling tendency than normal pellet. Another advantage is that the pellet in P-SCA may be acidic of less basic than the sinter mass surrounding of it. Acid pellet has much better reducibility. Thus, P-SCA has a very good application potential.

\subsection{Prospects of the techniques}

It has been mentioned above that iron ore has been used as a conventional coolant and lump lime as flux as well as coolant in the BOF steel making. However, the use of iron ore resulted severe foaming of steel bath and use of lump lime takes time for dissolution. Therefore, several

Table 9. Comparison among composite sinter and usual sinter.

\begin{tabular}{|c|c|c|c|c|c|c|c|c|c|c|c|}
\hline \multirow{2}{*}{$\begin{array}{l}\text { SI } \\
\text { No }\end{array}$} & \multirow{2}{*}{$\begin{array}{l}\text { Sinter } \\
\text { Group }\end{array}$} & \multirow{2}{*}{$\begin{array}{c}\text { Pellet Used, } \\
\%\end{array}$} & \multirow{2}{*}{$\begin{array}{l}\text { Sinter } \\
\text { Basicity }\end{array}$} & \multirow{2}{*}{$\begin{array}{c}\mathrm{MgO} \\
\text { content, } \%\end{array}$} & \multirow{2}{*}{$\begin{array}{c}\text { Overall coke } \\
\text { rate, } \%\end{array}$} & \multicolumn{2}{|c|}{$\begin{array}{l}\text { Yield } \\
(\%)\end{array}$} & \multirow{2}{*}{$\begin{array}{l}\text { Shatter index (\% } \\
\quad+5 \mathrm{~mm})\end{array}$} & \multirow{2}{*}{$\begin{array}{c}\text { Tumbler Index\% } \\
(+6.35 \mathrm{~mm})\end{array}$} & \multirow{2}{*}{$\begin{array}{l}\mathrm{Rl} \\
\%\end{array}$} & \multirow{2}{*}{$\begin{array}{r}\mathrm{RD} \\
\% \\
\end{array}$} \\
\hline & & & & & & $+5 \mathrm{~mm}$ & $+10 \mathrm{~mm}$ & & & & \\
\hline 1 & P-SCA & 30 & 2.1 & 1.7 & 5.1 & 68.2 & 55 & 91 & 74.2 & 70 & 27 \\
\hline 3 & $\begin{array}{l}\text { Usual } \\
\text { Sinter }\end{array}$ & 0 & 2.1 & 1.7 & 6.5 & 66.3 & 57 & 90 & 83.1 & 66 & 25 \\
\hline
\end{tabular}


investigators have used waste oxides of steel plant in form of cold bonded briquettes or pellets as coolant as well as refining agent. Although it shows improvement in refining process, there are several problems such as;

(i) It uses a considerable amount of organic or inorganic binders. While organic binder is very costly, inorganic binder contains high alumina and silica.

(ii) It requires a long (several days) curing time.

(iii) It contains considerable moisture, due to which the crumbling of briquettes may happen at high temperature of BOF.

Therefore, the binder-less process for the preparation of FLIP is developed. This process uses $\mathrm{CO}_{2}$ or $\mathrm{CO}_{2}$ containing industrial waste gas for the strengthening of the pellets, which make it environment friendly. The all raw materials are waste oxides. The whole process is operative at ambient temperature. Thus, the energy consumption in this process is also very low. Therefore, this technique is expected to be of low cost. Although, the techno economic could not be calculated from the laboratory scale experiments.

Like wise prefused synthetic flux (PSF) has been developed without using any coke breeze utilizing plant's waste material. The oxidation of metallic $\mathrm{Fe}$ in LD sludge and $\mathrm{C}$ in BF flue dust provides required heat for sintering. Therefore, this process is also not cost intensive and the $\mathrm{CO}_{2}$ emission is lower than conventional sintering.

The improvement in reducibility of iron ore pellet has been found to improve up to $7-8 \%$ by optimizing the process parameters viz. lowering induration temperature to $1275^{\circ} \mathrm{C}$, grain size of iron ore, flux and coke particles. No chemical change is there. The reduction in temperature indicates less $\mathrm{CO}_{2}$ emission. This can be implemented in plant only by modification of existing practice without any extra investment. On the other hand, RDI improvement by salt solution treatment is a room temperature process after preparation and induration of pellet. No emission is there. It can be implemented in any plant without any major investment. However, techno-economics can be assessed after its large-scale trial.

In a conventional sintering, there is a restriction of undersize fines. The green balling technique can utilize $20-30 \%$ microfines in normal iron ore sintering practice. Both micro-pelletizing technique and P-SCA preparation can improve fines utilization up to $60 \%$. Micro-pelletizing improves permeability of sinter bed. On the other hand, P-SCA sintering reduces coke breeze consumption and improves the bed permeability. Thus, energy consumption is reduced. However, the feasibility of P-SCA preparation in large scale needs to be developed.

All the above techniques are developed in laboratory in 10-12 kg scale. For their scaling up, a support from the steel industries is required. The above processes use waste materials and are not so cost intensive. However, only on the basis of result from plant trial, a technoeconomic evaluation is possible.

\section{Conclusions}

In sintering practice there is limitation of using micro-fines of iron oxides which are generated in steel plant as well as in mines area. In pelletizing, the micro fines are used however; due to the adverse chemistry and size restriction, some micro-fines are not used. Several techniques are developed for their utilization. Flux with lime iron oxide combination can provide low melting oxidizing slag in BOF. These low meting flux has been developed either by $\mathrm{CO}_{2}$ treated binderless pellet or by coke breeze free sintering of micro-pellets made from LD sludge and $\mathrm{BF}$ flue dust. Earlier one is infused flux and later one is partially fused flux. Both have shown very good performance in faster refining of steel bath. However, later one has shown much better performance. In these techniques, alkali has no adverse effect.

For enhancing micro-fines recycling, use of pellet and better quality pellet preparation is required. In order to improve the pellet quality, RI of pellet has been improved by $7-8 \%$ point than the normal pellet by optimizing the process parameter viz. fineness, induration temperature, apparent porosity etc. without changing pellet chemistry. Reduction degradation of pellet has been improved by treating it with several salt solutions. Treatment in $1-2 \% \mathrm{NaCl}$ solution has shown a significant improvement in RDI. The conventional binder, bentonite, which increases silica and alumina in pellet has been replaced by use of calcined lime keeping the basicity constant.

Use of micro fines in sintering has been improved by adopting micro-pelletizing technology. Coal fines or BF flue dust has also been used in micro-pellets which reduces the requirement of coke breeze in sintering. P-SCA has better shatter tumbler and other metallurgical properties than normal sinter. It consumes less energy than conventional sinter and also improves microfines utilization by $30 \%$. Thus, these technologies may be the solution for the better utilization of micro-fine waste iron oxides. Steel industries have to come forward with us for their upscaling which will help assessing the technoeconomic feasibility.

\section{Acknowledgment}

Author wishes to express his sincere gratitude to the Director CSIR-NML for his kind permission to publish this paper.

\section{Disclosure statement}

The author reports no conflicts of interest. The author alone is responsible for the content and writing of the article.

\section{Funding}

Author thankfully acknowledges the Ministry of Steel, Government of India, New Delhi and M/s Tata Steel, Jamshedpur, India for their financial assistance in some of these works.

\section{References}

Ahmed, Y. M. Z., and Mohamed, F. M., 2005, "Variation in physicochemical properties of iron oxide pellets using bentonite with calcium hydroxide as binder." La Metallurgia Italiana, 11-12. pp. 31-37. 
Alanko, A. M., and Atwell, W. H., 1987, "Mixed binder systems for agglomerates." U S Patent 4659374A.

Ambesh, C. P., 2007, "Iron Ore", Indian Mineral Year Book-2006." Indian Bureau of Mines, Nagpur, India, Govt. of India, Ministry of Mines, pp. 47, 15-47, 28.

Ammasi, A., and Pal, J., 2016. "Replacement of bentonite in hematite ore palletization using a combination of sodium lignosulphonate and copper smelting slag." Ironmaking and Steelmaking, 43(3). pp. 203213. doi:10.1179/1743281215Y.0000000033

Anon, 1997. "Reprocessing of steel plant fines." Steel Times, 225(1). pp. 32. (Accessed 2014 April 3), en-us/mining/Pages/Iron-Ore-withLime-Pelletizing-Case-Study-.aspx

Anon, 2013, "Iron ore with lime pelletizing case study." Pilot Plant Trial Report, Clariant Mining, May, Available from http://www.oms.clar iant.com/

Ansari, Q. A. K., Ahier, S. J., and Singer, A. R. E., 1984. "Crushing strength and reduction of bitumen-bonded magnetite superconcentrate." Iromaking and Steelmaking, 11(5). pp. 237-245.

Aota, J., Morin, L., Zhuang, Q., and Clements, B., 2006. "Direct reduced iron production using cold bonded carbon bearing pellets part 1 laboratory metallisation." Ironmaking and Steelmaking, 33(5). pp. 426-428. doi:10.1179/174328106X118053

Balajee, S. R., Callaway, P. E., Jr Kilman, L. M., and Lohman, L. J., 1995, "Production and BOF recycling of waste oxide briquettes containing steel making sludges, grit and scale at Inland" Proceedings of 78 th Steel Steelmaking Conf. pp. 51-65, Nashville, TN, ISS-AIME.

Ball, D. F., Dartnell, J., Davision, J., Grieve, A., and Wild, R., 1973. Agglomeration of Iron Ores, 1st, NewYork: Elsevier. pp. 266-275, 300.

Basu, G. S., Sarkar, P. K., Sharma, R. P., Ahmad, A., and Dhillon, A. S., 1997. "Recycling and re-use of solid waste at tata steel." Tata Search, pp. 118-120.

Basu, G. S., Sharma, R. P., and Dhillon, A. S., 2002. "Steel industry and climate change." Tata Search, pp. 39-42.

Bin, X. U., Hou, T., Chen, X., Li, Q., Jiang, T., and Li, P., 2013, "Effect of dolomite on reduction swelling property of iron ore pellets." Journal Center Southern University, 20. pp. 2806-2810.

Botelho, M. E. E., Nogueira, P. F., and Potter, S. M., 2014, "Process for the improvement of reducibility of ore pellets." US Patent No 2014/0096650 A1.

Catherine, L. M., and Freuhan, R. J., 2000, "Waste oxide recycling during oxygen steel making." Proceedings of 83 rd Steelmaking Conf. pp. 303313, Pittsburgh, ISS-AIME.

Chaudhary, P., Chaudhary, M. K., Gupta, S. S., Das, B. K., and Sandhu, H. S., 2001. "Use of pre-pelletised LD sludge in iron ore sintering." Tata Search, pp. 107-109.

Chizhikova, V. M., and Vainshtein, R. M., 2003. "Composition of ironore pellets with different types of additives." Metallurgy, 47(9-10). pp. 349-352. doi:10.1023/B:MELL.0000015261.33342.21

Choi, H. S., and Kim, J. S., 2002, "Improvement of the BOF operation using fluxing material containing Fe-oxide and silica." Proceedings of $85^{\text {th }}$ Steelmaking Conf., pp. 573-581 Warrendale, PA, ISS-AIME.

De Souza, R. P., 1976, "Production of pellets in CVRD using hydrated lime as binder, is growing up fast." Proceedings of 35th Annual Ironmaking Conf. pp.182-196, New York, ISS-AIME.

Dukelow, D. A., Warner, J. P., and Smith, N. H., 1995, "Use of waste oxides in the grate lake BOP" Proceedings of $78^{\text {th }}$ Steelmaking Conf., pp. 67-72, Nashville, TN, ISS-AIME.

Eisele, T. C., and Kawatra, S. K., 2003. "A review of binders in iron ore pelletization." Miner Proce Extract Metall Reviews. 24. pp. 1-90. doi:10.1080/08827500306896

Fan, X., Gan, M., Jiang, T., Yuan, L. S., and Chen, X., 2010. "Influence of flux additives on iron ore oxidized pellets." Journal Cent.South University Tecchnol. 17. pp. 732-737. doi:10.1007/s11771-010-0548-7

Forsmoa, S. P., and Hagglund, E. A., 2003. "Influence of the olivine additive fineness on the oxidation of magnetite pellets." International Journal Miner Processing. 70. pp. 109-122. doi:10.1016/ S0301-7516(02)00155-2

Franklin, R. L., James, G., Guseman, R., and Township, H., 1965, "Method and composition for making carbonate-bonded agglomerates." US patent, No 3,205,063.
Gao, Q., Ruan, Z., Chun, T., and Pan, J., 2014. "Charasteristics of calcined magnesite \& its application in oxidized pellet production." Journal of Iron and Steel Research, International, 21(4). pp. 408-412. doi:10.1016/S1006-706X(14)60063-7

George, I. J. L., 1968, "Ore agglomerates and methods of making the same." US patent, No. US3382063 A. doi:10.1055/s-0028-1105114

Haas, L. A., Aldinger, J. A., and Zahl, R. K., 1989, "Effectiveness of organic binders for Iron ore pelletization." Report of Investigation-RI 9230, Minneapolis, U.S Bureau of Mines, pp. 1-20.

Holley, C. A., 1985, "Agglomeration of steel plant waste for recycling." Proceedings of 19th Biennial Conf. pp.165-177, IBA, Baltimore, Maryland, Institute for Briquetting and Agglomeration (IBA).

Imazumi, T., 1991. "Recycling of LD converter sludge and iron bearing fines using NCP cold bonded process." Conservation and Recycling, 6 (4). pp. 167-179. doi:10.1016/0361-3658(83)90003-6

Indian mineral year Book, 2012, Part III, $51^{\text {st }}$ Edition, Iron Ore, Indian Bureau of Mines, Govt. of India, Nagpur India. www.ibm.nic.in

Irmler, B., Klimek, K., Piegza, K. Z., Galperine, G., Petrounine, M., Schrader, B., and Opletal, J., 2003, "Metallurgically engineered flux for liquid steel making." Proceedings of ISSTech Conference, pp. 1157-1165, Indianapolis,Indlana, ISS-AIME.

Jiang, T., Li, G. H., Wang, H. T., Jhang, K. C., and Jhang, Y. B., 2010. "Composite agglomeration process (CAP) for preparing blast furnace burden." Ironmaking and Steelmaking. 37. pp. 1-7. doi:10.1179/ 174328109X462995

Kawatra, S. K., and Ripke, S. J., 2003a. "Laboratory studies for improving green ball strength in bentonite-bonded magnetite concentrate pellets." International Journal Miner Processing. 72. pp. 429-441. doi:10.1016/S0301-7516(03)00117-0

Kawatra, S. K., and Ripke, S. J., 2003b. "Studies on the relationship between plate water absorption and unfired iron ore pellet strength." Minerals and Metallurgical Processing, 20(1). pp. 15-20.

Landow, M. P., Torok, J. F., Burnett, T. P., Crum, J. F., and Nelesen, J., 1998, "An overview of steel mill waste oxide recycling by cold bonded roll briquetting.” Prceedings of Ironmaking Conf., pp. 1237-1242, March, Warrendale, PA, ISS-AIME.

Larrea, M. T., Cores, A., Gutierrez, A., and Formoso, A., 1998. "Surface behaviour of magnesium chloride coated iron ore sinter." Journal of Materials Science. 23. pp. 1151-1158. doi:10.1007/BF01154572

Lherbier, L. W., and Green, R. D., Galperine G, Petrounine M, Schrader B, Opletal J, 1995, "Metallurgically engineered flux for liquid steel making." Proceedings of ISSTech Conference, vol. 1, pp. 1157-1165, Indianapolis, Indlana, ISS-AIME.

Lingtan, K., Lu, Y., and Lu, W. K., 1983, "The role of magnesia in iron ore pellets." Scandinavian Journal Metall, 41. pp. 66-176.

Liu, H., 2003, "Self-reducing, cold-bonded pellets". US patent, No. US 7896963 B2

Md., M., Pramanik, S., and Pal, J., 2016, "Role of MgO and its different minerals on properties of iron ore pellet." Transaction IIM, 69. pp. 1141-1153.

Meyer, K., 1980. Pelletizing of Iron Ores, New York, USA: SpringerVerlag. pp. 136-138.

Nakano, M., Okada, T., Hasegawa, H., and Sakakibara, M., 2000. "Coke breeze-less sintering of BOF dust and its capability of dezincing." ISIJ International, 40(3). pp. 238-243. doi:10.2355/ isijinternational.40.238

Nasr, M. L., Omarm, A. A., Khedr, H., and El-Geass, A. A., 1995. "Effect of nickel oxide doping on the kinetics and mechanism of iron oxide reduction." ISIJ International, 35(9). pp. 1043-1049. doi:10.2355/ isijinternational.35.1043

Niwa, Y., Sakamoto, N., Komatsu, O., Noda, H., and Kumasaka, A., 1993. "'Commercial production of iron ore feeds containing a large amount of agglomerates using sinter fine ores." ISIJ International. 33. pp. 454461. doi:10.2355/isijinternational.33.454

Pal, J., Arunkumar, C., Rajshekhar, Y., Das, G., Goswami, M. C., and Venugopalan, T., 2014a. "Development on iron ore pelletization using calcined lime and $\mathrm{MgO}$ combined flux replacing limestone and bentonite." ISIJ International, 54(10). pp. 2169-2178. doi:10.2355/ isijinternational.54.2169 
Pal, J., Ghoaria, S., Ammasi, A., Hota, S. K., Koranne, V. M., and Venugopalan, T., 2017b. "Improving reducibility of iron ore pellets by optimization of physical parameters." Journal of Mining and Metallurgy, Section B: Metallurgy, 53(1). pp. 37-46. doi:10.2298/ JMMB151206014P

Pal, J., Ghorai, S., Agarwal, S., Nandi, B., Chakraborty, T., Das, G., and Prakash, S., 2015c. "Effect of blaine fineness on the quality of hematite iron ore pellets for blast furnace." Miner Processing Extr Metall Reviews. 36. pp. 83-91. doi:10.1080/08827508.2013.873862

Pal, J., Ghorai, S., Bandyopadhyay, D., and Ghosh, S., 2015b. "Performance assessment of partially pre-fused synthetic flux in basic oxygen steel making." Journal of Iron and Steel Researcher International, 22(10). pp. 916-923. doi:10.1016/S1006-706X(15)30090-X

Pal, J., Ghorai, S., and Das, A., 2015a. "Development of carbon composite iron ore micropellets by using the microfines of iron ore and carbon bearing materials in iron making." International Journal of Minerals Metallurgy and Materials, 22(2). pp. 132-140. doi:10.1007/s12613-015-1053-7

Pal, J., Ghorai, S., Goswami, M. C., Ghosh, S., Ghosh, D., and Bandyopadhyay, D., 2009a. "Development of fluxed iron oxide pellets strengthened by $\mathrm{CO}_{2}$ treatment for use in basic oxygen steel making." ISIJ International, 49(2). pp. 210-219. doi:10.2355/isijinternational.49.210

Pal, J., Ghorai, S., Goswami, M. C., Prakash, S., and Venugopalan, T., 2014b. "Development of pellet-sinter composite agglomerate for blast furnace." ISIJ International, 54(3). pp. 620-627. doi:10.2355/ isijinternational.54.620

Pal, J., Ghorai, S., Nandi, B., Chakraborty, T., Das, G., and Venugopalan, T., 2015d. "Effect of pyroxenite and olivine minerals as source of $\mathrm{MgO}$ in hematite pellet on improvement of metallurgical properties." Journal Center Southern University, 22(9). pp. 3302-3310. doi:10.1007/s11771-015-2870-6

Pal, J., Ghorai, S., Rajshekar, Y., and Koranne, V. M., 2017a. "Development of blast furnace quality pellet optimising blue dust, hard ore and friable ore ratio." Ironmaking and Steelmaking, 44(8). pp. 568-576. doi:10.1080/03019233.2016.1222778

Pal, J., Ghorai, S., Singh, D. P., Goswami, M. C., Bandyopadhyay, D., and Ghosh, D., 2011. "Dissolution characteristics of CO2-treated fluxed pellets in hot metal bath." Mineral Processing and Extractive Metall Reviews. 32. pp. 229-246. doi:10.1080/08827508.2010.530717

Pal, J., Ghorai, S., Singh, D. P., Upadhyay, A. K., Ghosh, S., Ghosh, D., and Bandyopadhyay, D., 2010. "Performance assessment of $\mathrm{CO}_{2}$ treated fluxed iron oxide pellets in basic oxygen steel making process." ISIJ International, 50(1). pp. 105-114. doi:10.2355/isijinternational.50.105

Pal, J., Ghorai, S., Venkatesh, P., Goswami, M. C., and Bandyopadhyay, D., 2013b. "Development of prefused synthetic flux for basic oxygen steel making through micro-pelletization and sintering of iron oxide fines." Steel Research International, 84(11). pp. 1115-1125. doi:10.1002/srin.v84.11

Pal, J., Ghorai, S., Venkatesh, P., Goswami, M. C., Bandyopadhyay, D., and Ghosh, S., 2013a. "Development of fluxed micro-pellets for sintering utilizing iron oxide wastes fines." Ironmaking and Steelmaking, 40(7). pp. 498-504. doi:10.1179/1743281212Y.0000000069

Pal, J., Goswami, M. C., Mahato, B., Ghosh, S., Ghosh, D., and Bandyopadhyay, D., 2009b. "High temperature characterization of $\mathrm{CO}_{2}$ treated fluxed pellets developed for basic oxygen steel making." ISIJ International, 49(9). pp. 1325-1332. doi:10.2355/isijinternational.49.1325

Pal, J., and Venugopalan, T., 2015. "Carbon as in situ energy source in induration of hematite pellets and its effect on pellet properties." Ironmak. Steelmak., 42(2). pp. 139-147. doi:10.1179/ 1743281214Y.0000000215

Panigraphy, S. C., Choudhury, A., Rigaud, M., and Lein, H. O., 1989, "Effect of micro-pelletization on the structure and properties of sinters produced from a Canadian mix containing high percentage of specularite concentrate." Proceedings of the $5^{\text {th }}$ International Symp. on Agglomeration, pp. 13-31, Brighton, UK, Institution of Chemical Engineers.
Parkes, G. D., 1961. Mellor's Modern Inorganic Chemistry, 5th, London: Longmans Green and Co. pp. 697.

Perry, R. H., and Chilton, C. H., 1973. Chemical Engineers' Hand Book, 5th, New York: McGraw-Hill. pp. 3, 10.

Ranjan, P., and Pal, J., 2016. "Salt solution treatment to prevent the low temperature reduction degradation of haematite pellet." Ironmaking and Steelmaking, 43(9). pp. 688-696.

Rankin, W. J., and Rolloer, P. W., 1985, "The iron measurement of void fraction in beds of granulated ore sinter feed." Transactions ISIJ, 25. pp. 1016-1020.

Sakamoto, N., Kumasaka, A., Kamatsu, Q., Shimizu, M., and Noda, H., 1989, "Development of new iron ores agglomeration process." Proceedings of the $5^{\text {th }}$ International Symp. on Agglomeration, pp.269-278 Brighton, UK, Institution of Chemical Engineers.

Sarangi, A., and Sarangi, B., 2011. Sponge Iron Production in Rotary Kiln, New Delhi: PHI Learning Pvt. Ltd. pp. 156.

Sarkar, A., Mandal, A. K., and Sinha, O. P., 2013, "Pelletisation behaviour of fluxed iron ore pellets of varying basicities made with waste fines." International Journal Sciences Engineering, 5. pp. 9-14.

Sastry, K. V. S., Negam, A., and Kater, A., 1985, "Role of binders during pelletization of iron ore concentrates- pellet growth and strength aspect." Proceedings of 4th International Symposium on Agglomeration, pp. 41-48, Toronto, Canada, June, ISS-AIME.

Semberg, P., Rutqvist, A., Andersson, C., and Bjorkman, B., 2011. "Interaction between iron oxides and olivine in magnetite based pellets during reduction at temperatures below $1000^{\circ} \mathrm{C}$." Ironmak Steelmak, 38(5). pp. 321-328.

Shigaki, I., Shirouchi, S., Tokutake, K., and Ohasegaw, N., 1990. "Study and improvement of reduction retardation and melt-down properties of pellets." ISIJ International, 30(3). pp. 199-207.

Shivaramakrishna, N., Agarwal, B. B., Ray, A. K., Prasad, K. K., Bandopadhyay, P. K., and Gupta, S. K., 1990. "Effects of binder on the properties of iron ore-coal composite pellets." Transactions of the Indian Institute of Metals, 43(2). pp. 95-101.

Srivastava, U., Kawatra, S. K., and Eisele, T. C., 2013. "Study of organic and inorganic binders on strength of iron oxide pellets." Metallurgical and Materials TransactionsB, 44B(4). pp. 1000-1009.

Taguchi, N., Otomo, T., and Omori, Y., 1990. "Immersion treatment of sinter into calcium halide solution." ISIJ International, 30(4). pp. 281289.

Umadevi, T., Kumar, P., Lobo, N. F., Prabhu, M., Mahapatra, P. C., and Ranjan, M., 2011. "Influence of pellet basicity $(\mathrm{CaO} / \mathrm{SiO} 2)$ on iron ore pellet properties and microstructure." ISIJ International, 51(1). pp. $14-20$.

Umadevi, T., Kumar, P. P., Kumar, M. G. S., Kumar, S., and Ranjan, M., 2008. "Influence of carbon addition via Corex sludge on pellet quality at JSW steel." Ironmak Steelmak, 35(6). pp. 421-429.

Umadevi, T., Lobo, N. F., Desai, S., Mahapatra, P. C., Sah, R., and Prabhu, M., 2013. "Optimization of firing temperature for hematite pellets.” ISIJ International, 53(9). pp. 1673-1682.

Verein Deutscher Eisenhulttenleute, 1981. Slag Atlash, Dusseldrof: VerlagStahleisen, MBH. 37. pp. 37.

Wang, D., and Wu, S., 2014. "Estimation of oxidized pellets of a Brazilian hematite concentrate by adding serpentine." ISIJ International, 54(4). pp. 715-720.

$\mathrm{Xu}$, Z., Jian-liang, Z., Zheng-wen, H., Hai-bin, Z., and Hong-wei, G., 2010. "Effect of $\mathrm{CaCl}_{2}$ on the RDI \& RI of sinter." Journal of Iron and Steel Research, International, 17(11). pp. 07-12.

Yadav, U. S., Das, B. K., Kumar, A., and Sandhu, H. S., 2002, "Solid wastes recycling through sinter -status at tata steel, proceedings on clean technologies for metallurgical industries." Proceedings of EWM, pp. 81-94, January Jamshedpur, India.

Yanaka, H., and Ohno, Y., 1991, "Method for manufacturing cold bonded pellets." US patent 